Article

\title{
Monitoring Sustainable Development: Climate and Energy Policy Indicators
}

\author{
Claudia Kettner ${ }^{1, *}$, Daniela Kletzan-Slamanig ${ }^{1}$, Angela Köppl ${ }^{1}$, Beate Littig ${ }^{2}$, \\ Irina Zielinska ${ }^{2}$ \\ 1 Austrian Institute of Economic Research (WIFO), Arsenal Objekt 20, 1030 \\ Vienna, Austria \\ 2 Institute for Advanced Studies (IHS), Josefstädter Str. 39, 1080 Vienna, Austria \\ * Correspondence: Claudia Kettner, Email: claudia.kettner@wifo.at; \\ Tel.: +43-1-798-2601-406.
}

\begin{abstract}
Both the UN SDGs and the Paris Agreement imply ambitious long-term targets that can only be met through a fundamental restructuring of economic and social systems. We propose a set of energy and climate policy indicators that allow informed policymaking and go beyond the UN indicator set. The indicators cover the whole energy system as well as the three dimensions of sustainable development. Our approach combines an energy service centered perspective with research on energy and climate indicators, and it embeds the indicator framework in the broader socio-ecologic context. We compile a set of 109 high-level energy indicators for four key sectors of energy demand (households, transport, industry and manufacturing) that can be further disaggregated to 334 indicators. For electricity and heat supply we assemble a set of 21 indicators that can be disaggregated to 54 indicators, differentiating by energy source and plant type. Interactions, i.e., synergies and conflicts, between the different target dimensions and the corresponding indicators need to be carefully considered. The main aim of the comprehensive indicator set is to help policymakers define measurable goals and strategies in the field of energy and climate policy, as well as to provide a tool for policy monitoring, evaluation and revision. The challenge in using indicator systems for policy analysis is that they have to consider a multitude of aspects in order to reflect the complexity of the issues analyzed and at the same time have to deliver concise information on various trends.
\end{abstract}

Accepted: 23 May 2020

Published: 28 May 2020

Copyright (c) 2020 by the author(s). Licensee Hapres, London, United Kingdom. This is an open access article distributed under the terms and conditions of Creative Commons Attribution 4.0 International License.

KEYWORDS: sustainable development; indicator systems; energy policy; climate policy

\section{INTRODUCTION}

2015 was marked by two important outcomes of international negotiations: the agreement on the UN Sustainable Development Goals (SDGs) and the Paris Climate Agreement. Both imply ambitious (long-term) 
targets that can only be met with a fundamental restructuring of economic and social systems. The greenhouse gas (GHG) emission reductions-required to limit climate change to well below $2{ }^{\circ} \mathrm{C}$ or even $1.5{ }^{\circ} \mathrm{C}$ above pre-industrial levels, as stated in the Paris Climate Agreement-call for a fundamental decarbonization. A substantial contribution needs to come from the energy system because energy-related emissions account for the largest share in total GHG emissions, e.g., $78 \%$ for the EU total [1].

For both the Paris Agreement and the SDGs, research is needed because the scope of the required changes calls for new measurement and monitoring approaches. This comprises work on governance structures, pathway analyses, as well as suitable indicator sets that comprehensively capture the socio-economic and environmental aspects and allow depicting synergies and trade-offs between the dimensions of sustainable development as well as between targets [2,3]. Therefore, indicator sets that provide more detailed information than the set of targets and indicators proposed by the UN are called for. In this paper, we propose a novel Climate and Energy Policy (ClEP) indicator system for the EU Member States that allows for informed policymaking. Compared to those approaches which mainly focus on progress based on the UN indicator set [4], our indicator system contains more disaggregated information with a focus on energy and climate policy. The proposed sustainable energy indicators cover the entire energy system as well as the three dimensions of sustainable development. The approach combines an energy service centered perspective with research on energy and climate indicators, and it embeds the indicator framework in a broader socio-ecologic context. The main aim of the comprehensive indicator set is to help policymakers define measurable goals and strategies in the field of energy and climate policy and to provide a tool for policy monitoring, evaluation and revision. For the EU Member States, relevant data so far are mainly available at the national level. Therefore, the relevant target group is national energy and climate policymakers, allowing them to conduct performance comparisons and to identify successful solutions. Moreover, some of the indicators could complement the existing energy and climate policy indicators at the EU level. One key advantage of our indicator system is its ability to facilitate public debate on trade-offs between different targets, thereby providing a basis for informed decision-making.

For a series of issues, in particular pertaining to the social dimension of sustainable energy development, at present no data are available and therefore have to be omitted from the analysis. The closing of the gap has to be spurred by policymakers (in providing the legal basis for data collection) and statistical offices in actual data collection and processing. This would help identify interlinkages and trade-offs between the dimensions of sustainable development as well as between different sectors. 
The paper is structured as follows: The second section provides the broader context, embedding the climate and energy policy indicators into the socio-ecological framework defined by the UN Sustainable Development Goals. In the third section the conceptual approach of the ClEP indicator framework is presented. The fourth section discusses interactions between the target dimensions and indicators. The final section concludes.

\section{CLIMATE AND ENERGY POLICY INDICATORS IN THE CONTEXT OF THE UN SDGS}

The manifold interactions between the 17 SDGs and different sub-targets constitute a broad research area [2,5-10]. The assessment of interlinkages is of high relevance because ignoring synergies or trade-offs creates a risk of unintended outcomes. This applies to the entirety of the SGDs but also to the set of energy and climate policy indicators described below. Figure 1 illustrates which thematic areas of SDGs 7 and 13 we identified as being strongly or directly linked to eleven other goals and which interactions between these objectives must be considered to achieve the targets and design adequate monitoring approaches. For instance, policies aimed at reducing energy expenditures of poor households (thus contributing to improvements in the social dimension/SDG 10) might increase energy demand and in turn emissions (with negative effects on the environmental dimension/SDG 13), if not properly designed.

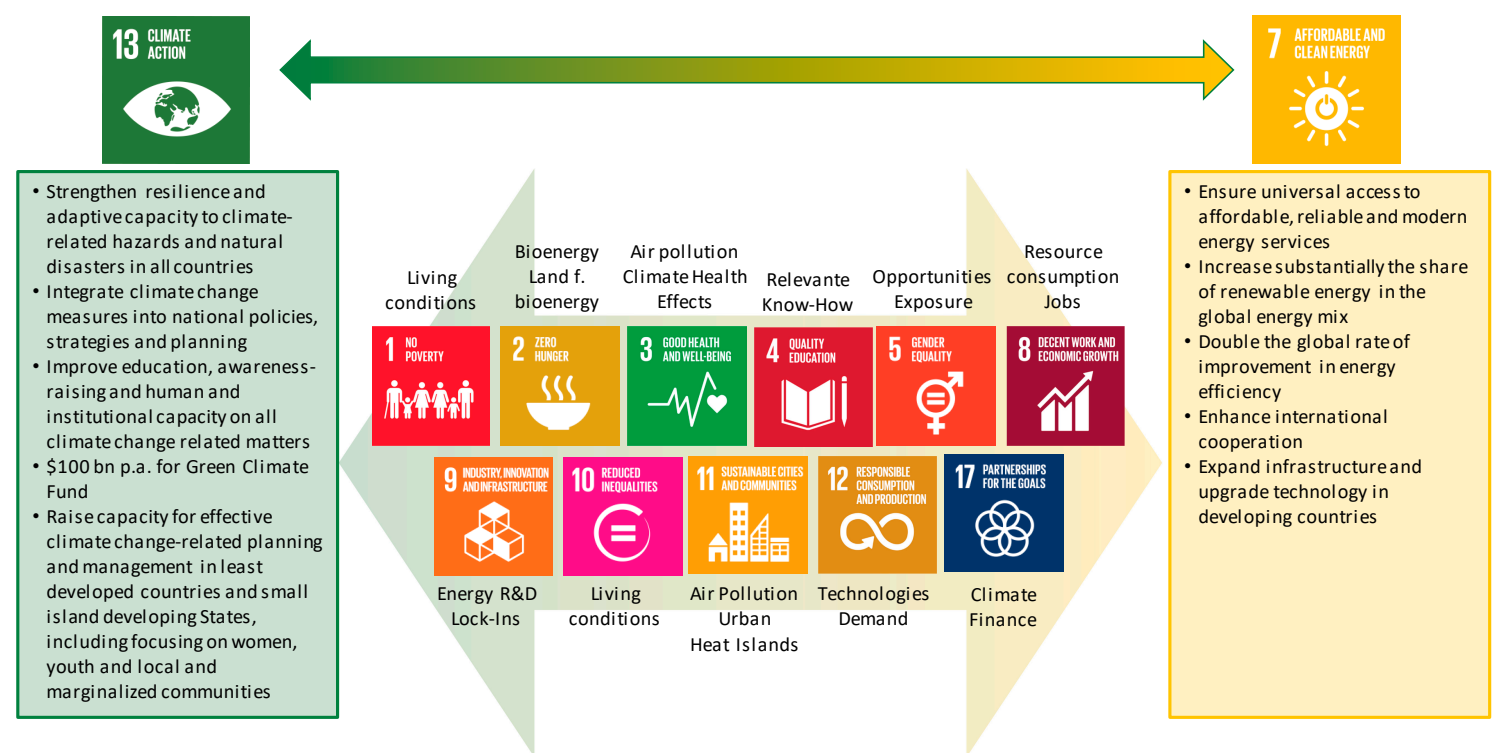

Figure 1. Interaction of the SDGs "Climate Action" and "Affordable and Clean Energy" with other SDGs; authors' own illustration.

The indicator set is embedded in the broader socio-ecological framework defined by the UN SDGs but specifically focuses on two goals: "Affordable and clean energy" (SDG 7) and "Climate Action" (SDG 13). It consists of operational indicators putting energy services at the center 
because energy services generate welfare instead of energy flows [11-17]. The indicator set starts with energy services in four demand-side sectors-residential buildings, transport, manufacturing and services-which are complemented by consistent indicators for sustainable electricity and heat supply.

Figure 2A presents a conceptual illustration for a better understanding of the interlinkages between the SDGs. We use a "doughnut" representation similar to other research concerned with the SDGs [18], in which the socio-ecological framework is partitioned into three layers-wellbeing, governance and planetary boundaries [2], and to which the SDGs are assigned in the context of our research. This combination of the concept of wellbeing and the concept of planetary boundaries creates a space in which sustainable development can be achieved, i.e., social goals are met while at the same time the integrity of ecosystems is preserved so that they can provide the services on which our societies depend. In this visualization we attribute ten SDGs to the layer of wellbeing (inner layer). The second layer of governance structures constitutes the supporting framework for wellbeing and comprises three SDGs. The third layer comprises the planetary boundaries, i.e., the biophysical base and natural limits for all human activities.

As emphasized in TWI2050 [19], the starting point for any clustering of SDGs must be the definition of the research question for which it is of relevance. There is no "absolute" categorization of the SDGs because they do not comprise a specific model, but TWI2050 [19] concluded that "(i) the SDGs are universal, holistic and interdependent and thereby indivisible, and (ii) any clustering method is context specific, being dependent on the question being addressed, modelling approach, or regional context.”

To develop this representation or clustering of SDGs we focused on human wellbeing and those goals that directly affect living conditions and quality of life. Our energy system approach [14] can then be integrated into this perspective (Figure 2(B)). This allows considering in more detail to what extent energy services, i.e., the use derived from "consuming" energy, are crucial for all aspects of economic and social development. A given level of energy services can be provided by different combinations of technologies (stocks) and energy flows. The range of available technologies and energy sources thus opens up a spectrum of options entailing different environmental impacts for any given energy service level. The energy efficiency of the capital stock (i.e., both of conversion technologies and application technologies/passive systems) is one key determinant of energy flows and the corresponding greenhouse gas emissions associated with a certain level of energy services $[11,14,15]$. In contrast to the welfare-inducing energy services, the physical aspects of energy (flows) and related greenhouse gas emissions are part of the "planetary boundaries". 


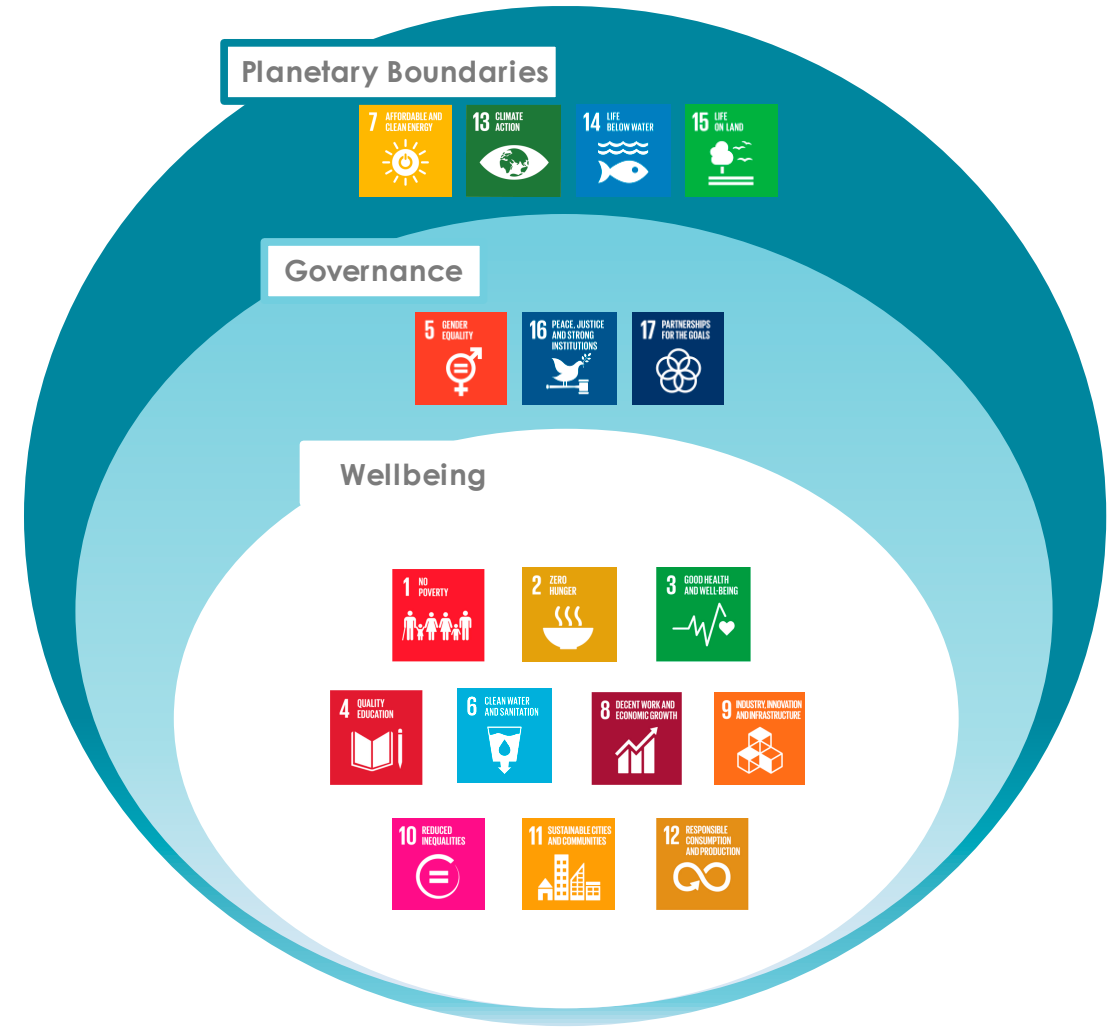

(A) Embedding the SDGs into the broader socio-ecological context

Figure 2. Socio-ecological context; authors' own illustration.

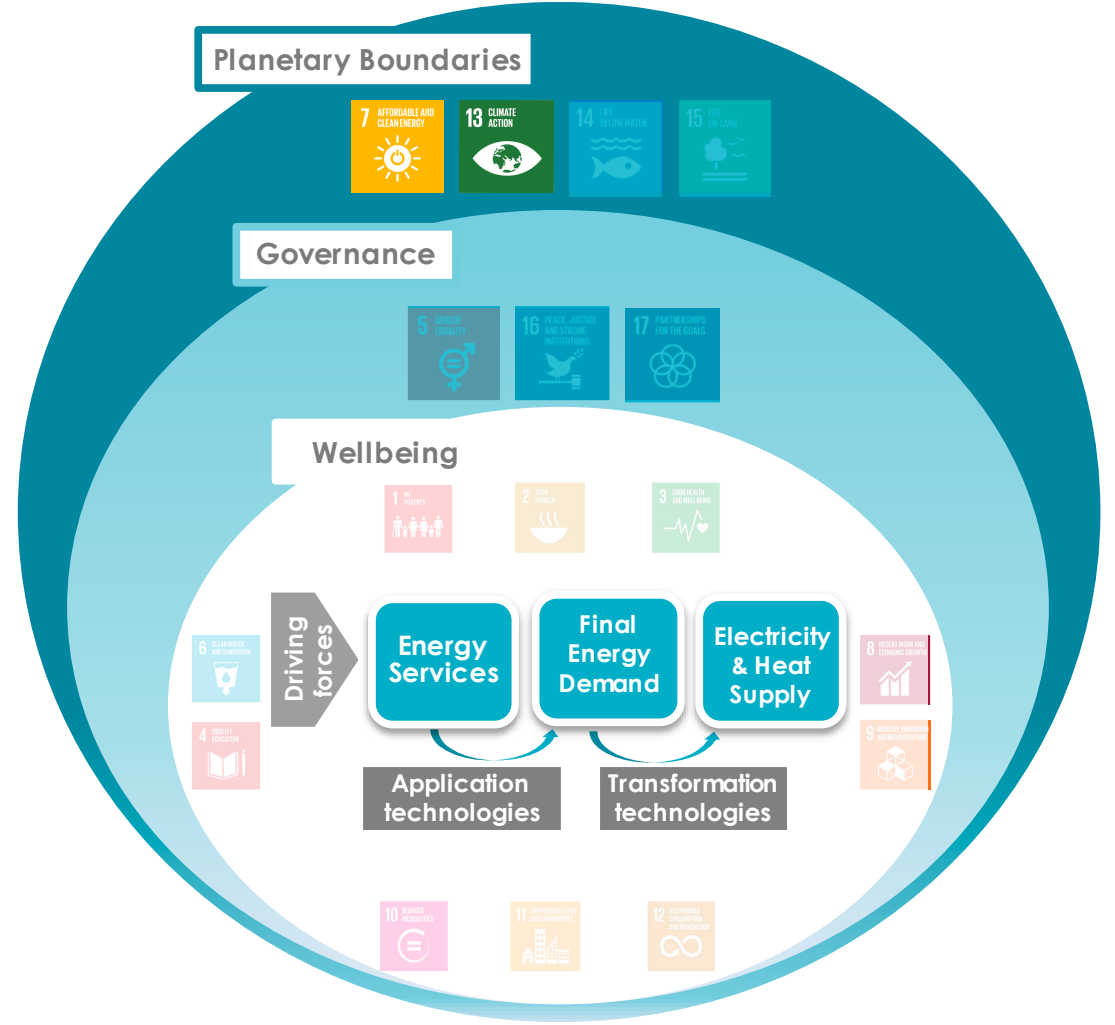

(B) Embedding the ClEP indicator approach into the broader socio-ecological context 
Thus, the detailed indicator set describes or quantifies the areas of energy and climate, on the one hand, but emphasizes the relevance of these areas for people's wellbeing, on the other. And while the interlinkages between energy and climate are at the center of our analysis, interlinkages with other SDGs, although highly relevant (see also Figure 1), are beyond the scope of this research.

\section{THE CLEP INDICATOR FRAMEWORK}

\section{Literature Overview}

The multidimensionality of sustainable development entails a high degree of complexity. Sets of indicators-such as those developed, for instance, by the EU and the UN [20-24] - are considered to be appropriate tools with which to reduce this complexity and to illustrate the interactions between society and ecosystems.

The adoption of the SDGs and the publication of the corresponding indicator framework have stimulated the latest wave of developing comprehensive indicator frameworks. The SDGs of the 2030 Agenda for Sustainable Development are the continuation of the Millennium Development Goals [23] and were adopted by 156 states in 2015 after an extensive planning and consultation process. In the SDGs, the overarching aims of ending all forms of poverty, protecting the planet and ensuring prosperity for everyone are broken down into 17 goals and 169 detailed targets. In contrast to the Millennium Development Goals, the SDGs refer not only to developing countries but to all signatories.

For the monitoring of the SDGs and the respective sub-targets, an indicator system comprising 244 indicators (or respectively 233 indicators, with some occurring more than once in the system) was developed, some of which are used to monitor more than one target [22]. In general, the goals/targets and the respective indicators are based on the three dimensions of sustainable development and can be divided into the five pillars of the Agenda 2030 (the five "Ps"-people, planet, prosperity, peace, partnership).

In the EU, the UN SDG framework has been implemented by Eurostat as well as at the Member State level, with national indicator frameworks differing from the Eurostat system. In the following, the indicators for SDGs 7 and 13 proposed by the UN are compared with the indicators put forward by Eurostat, and the indicators developed for Austria as an example of a national indicator framework. A different approach is applied by the Sustainable Development Solutions Network (SDSN) and the Bertelsmann Stiftung, who provide a composite SDG Index and dashboards describing countries' progress towards achieving the SDGs [25]. The 2018 SDG Index includes 88 global indicators and 111 indicators for the Dashboard for 156 OECD countries. Thirty-nine of these indicators match UN indicators exactly, 28 are closely aligned, and 44 are not included in the UN framework. 
Eurostat has developed its own indicator set that puts emphasis on interlinkages between targets by defining so-called multi-purpose indicators (monitoring more than one target). The Eurostat framework consists of 100 indicators, with a maximum of 6 indicators being assigned to each SDG.

For Austria, the national statistical office, Statistics Austria, implemented an indicator framework closely related to the UN indicators [26]. For almost half of the proposed UN indicators, national data are currently available from Statistics Austria or from other data sources. Forty-five indicators that are not relevant to Austria (e.g., indicators related to marine life or targeted at developing countries) have been omitted. For another 19\% of the proposed UN indicators no data for Austria are available. However, the national statistical office has added additional indicators that are of particular relevance from an Austrian perspective (headline indicators from the national wellbeing measurement initiative "Wie geht's Österreich").

Table 1 lists the indicators used for monitoring SDG 7 "Affordable and clean energy" and SDG 13 "Climate Action" developed by the UN, Statistics Austria and Eurostat, along with the sub-targets. The indicators by the UN and Statistics Austria largely correspond to the ten sub-targets. For SDG 7, these include providing access to affordable, reliable and modern energy services for all, substantially increasing the share of renewable energy and accelerating energy efficiency improvements, along with assistance for lower-income countries. While Statistics Austria has not adopted the indicators "7.1.1 Proportion of population with access to electricity" and "7.1.2 Proportion of population with primary reliance on clean fuels and technology" because these targets have already been achieved in Austria, final energy consumption has been included as an additional indicator. The six Eurostat indicators include information on energy poverty, final energy consumption, energy dependence, energy productivity and GHG emissions intensity of energy consumption as a multi-purpose indicator.

For SDG 13, the UN indicators focus mostly on a policy/finance dimension and cover both climate change mitigation and adaptation. Most indicators have a global dimension, e.g., "13.3.2 Number of countries that have communicated the strengthening of institutional, systemic and individual capacity-building to implement adaptation, mitigation and technology transfer, and development actions". Statistics Austria has omitted most of these global targets and adapted some of them to the national context. In addition, it included GHG emissions as an indicator. The Eurostat indicators, in contrast, focus on GHG emissions and the impacts of climate change. Moreover, Eurostat stresses the nexus between emissions and energy use by including final energy consumption and the share of renewables as multi-purpose indicators. 
Table 1. Indicators used by statistical offices for Monitoring SDGs 7 and 13.

\begin{tabular}{|c|c|c|c|}
\hline \multirow{2}{*}{ Goal/Target } & \multicolumn{3}{|c|}{ Indicators } \\
\hline & UN & Statistics Austria & Eurostat \\
\hline \multicolumn{4}{|c|}{ SDG 7. Ensure access to affordable, reliable, sustainable and modern energy for all } \\
\hline \multirow[t]{2}{*}{$\begin{array}{l}\text { 7.1 By 2030, ensure universal access to affordable, } \\
\text { reliable and modern energy services }\end{array}$} & $\begin{array}{l}\text { 7.1.1 Proportion of population with access to } \\
\text { electricity }\end{array}$ & $-\mathrm{a}$ & \multirow{7}{*}{$\begin{array}{l}\text { 07.10 Percentage of people affected by fuel } \\
\text { poverty (inability to keep home } \\
\text { adequately warm) } \\
\text { 07.20 Share of renewable energy in gross final } \\
\text { energy consumption } \\
\text { 07.30 Primary energy consumption; final energy } \\
\text { consumption by sector } \\
\text { 07.32 Final energy consumption in households } \\
\text { per capita } \\
\text { 07.33 Energy dependence }\end{array}$} \\
\hline & $\begin{array}{r}\text { 7.1.2 Proportion of population with primary } \\
\text { reliance on clean fuels and technology }\end{array}$ & $-\mathrm{a}$ & \\
\hline $\begin{array}{l}\text { 7.2 By 2030, increase substantially the share of } \\
\text { renewable energy in the global energy mix }\end{array}$ & $\begin{array}{l}\text { 7.2.1 Renewable energy share in the total final } \\
\text { energy consumption }\end{array}$ & $\begin{array}{l}\text { Renewable energy share in gross final } \\
\text { energy consumption }\end{array}$ & \\
\hline \multirow[t]{2}{*}{$\begin{array}{l}\text { 7.3 By 2030, double the global rate of improvement in } \\
\text { energy efficiency }\end{array}$} & $\begin{array}{l}\text { 7.3.1 Energy intensity measured in terms of } \\
\text { primary energy and GDP }\end{array}$ & $\begin{array}{l}\text { Energy intensity: Final energy } \\
\text { consumption per GDP }\end{array}$ & \\
\hline & - & Final energy consumption & \\
\hline $\begin{array}{l}\text { 7.a By 2030, enhance international cooperation to } \\
\text { facilitate access to clean energy research and } \\
\text { technology, including renewable energy, energy } \\
\text { efficiency and advanced and cleaner fossil-fuel } \\
\text { technology, and promote investment in energy } \\
\text { infrastructure and clean energy technology }\end{array}$ & $\begin{array}{l}\text { 7.a.1 International financial flows to } \\
\text { developing countries in support of clean } \\
\text { energy research and development and } \\
\text { renewable energy production, including } \\
\text { in hybrid systems }\end{array}$ & $\begin{array}{l}\text { International financial flows to } \\
\text { developing countries in support of clean } \\
\text { energy research and development and } \\
\text { renewable energy production }\end{array}$ & \\
\hline $\begin{array}{l}\text { 7.b By 2030, expand infrastructure and upgrade } \\
\text { technology for supplying modern and sustainable } \\
\text { energy services for all in developing countries, in } \\
\text { particular least developed countries, small island } \\
\text { developing States and landlocked developing } \\
\text { countries, in accordance with their respective } \\
\text { programmes of support }\end{array}$ & $\begin{array}{l}\text { 7.b.1 Investments in energy efficiency as a } \\
\text { proportion of GDP and the amount of } \\
\text { foreign direct investment in financial } \\
\text { transfer for infrastructure and } \\
\text { technology to sustainable development } \\
\text { services }\end{array}$ & - & \\
\hline
\end{tabular}


Table 1. Cont.

\begin{tabular}{|c|c|c|c|}
\hline \multirow{2}{*}{ Goal/Target } & \multicolumn{3}{|c|}{ Indicators } \\
\hline & UN & Statistics Austria & Eurostat \\
\hline \multicolumn{4}{|c|}{ Goal 13. Take urgent action to combat climate change and its impacts } \\
\hline \multirow{3}{*}{$\begin{array}{l}\text { 13.1 Strengthen resilience and } \\
\text { adaptive capacity to } \\
\text { climate-related hazards and } \\
\text { natural disasters in all } \\
\text { countries }\end{array}$} & $\begin{array}{c}\text { 13.1.1 Number of deaths, missing persons and directly affected } \\
\text { persons attributed to disasters per } 100,000 \text { population }\end{array}$ & $\begin{array}{l}\text { Number of deaths attributed to disasters } \\
\text { per } 100,000 \text { population }\end{array}$ & \multirow{5}{*}{\begin{tabular}{|l} 
13.11 Greenhouse gas emissions (indexed totals \\
and per capita) \\
13.14 Greenhouse gas emissions intensity of \\
energy consumption \\
13.21 Global (and European) near surface \\
average temperature \\
13.45 Economic losses caused by climate \\
extremes (consider climatological, \\
hydrological, meteorological) \\
13.51 Contribution to the 100bn international \\
commitment on climate related \\
expending (public finance) \\
13.63 Share of EU population covered by the \\
new Covenant of Mayors for Climate and \\
Energy (integrating mitigation, \\
adaptation, and access to clean and \\
affordable energy) \\
07.20 Share of renewable energy in gross final \\
energy consumption c \\
07.30 Primary energy consumption; final energy \\
consumption by sector c \\
12.51 Average CO ${ }_{2}$ emissions per km from new \\
passenger cars ${ }^{c}$ \\
14.31 Ocean acidification c
\end{tabular}} \\
\hline & $\begin{array}{l}\text { 13.1.2 Number of countries that adopt and implement national } \\
\text { disaster risk reduction strategies in line with the Sendai } \\
\text { Framework for Disaster Risk Reduction 2015-2030 }\end{array}$ & $\begin{array}{l}\text { National Crisis and Disaster } \\
\text { Management }\end{array}$ & \\
\hline & $\begin{array}{l}\text { 13.1.3 Proportion of local governments that adopt and } \\
\text { implement local disaster risk reduction strategies in line } \\
\text { with national disaster risk reduction strategies }\end{array}$ & & \\
\hline \multirow[t]{2}{*}{$\begin{array}{l}\text { 13.2 Integrate climate change } \\
\text { measures into national policies, } \\
\text { strategies and planning }\end{array}$} & $\begin{array}{l}\text { 13.2.1 Number of countries that have communicated the } \\
\text { establishment or operationalization of an integrated } \\
\text { policy/strategy/plan which increases their ability to } \\
\text { adapt to the adverse impacts of climate change, and } \\
\text { foster climate resilience and low greenhouse gas } \\
\text { emissions development in a manner that does not } \\
\text { threaten food production }\end{array}$ & Austrian National Adaptation Strategy & \\
\hline & - & Greenhouse gas emissions & \\
\hline
\end{tabular}


Table 1. Cont.

\begin{tabular}{|c|c|c|c|}
\hline \multirow{2}{*}{ Goal/Target } & \multicolumn{3}{|c|}{ Indicators } \\
\hline & UN & Statistics Austria & Eurostat \\
\hline \multicolumn{4}{|c|}{ Goal 13. Take urgent action to combat climate change and its impacts } \\
\hline \multirow{2}{*}{$\begin{array}{l}\text { 13.3 Improve education, } \\
\text { awareness-raising and human } \\
\text { and institutional capacity on } \\
\text { climate change mitigation, } \\
\text { adaptation, impact reduction } \\
\text { and early warning }\end{array}$} & $\begin{array}{l}\text { 13.3.1 Number of countries that have integrated mitigation, } \\
\text { adaptation, impact reduction and early warning into } \\
\text { primary, secondary and tertiary curricula }\end{array}$ & $-\mathrm{b}$ & \\
\hline & $\begin{array}{l}\text { 13.3.2 Number of countries that have communicated the } \\
\text { strengthening of institutional, systemic and individual } \\
\text { capacity-building to implement adaptation, mitigation } \\
\text { and technology transfer, and development actions }\end{array}$ & $-b$ & \\
\hline $\begin{array}{l}\text { 13.a Implement the commitment } \\
\text { undertaken by developed } \\
\text { country parties to the UNFCCC } \\
\text { to a goal of mobilizing jointly } \\
\$ 100 \text { billion annually by } 2020 \\
\text { from all sources }\end{array}$ & $\begin{array}{l}\text { 13.a.1 Mobilized amount of United States dollars per year } \\
\text { between } 2020 \text { and } 2025 \text { accountable towards the } \$ 100 \\
\text { billion commitment }\end{array}$ & $-\mathrm{a}$ & \\
\hline $\begin{array}{l}\text { 13.b Promote mechanisms for raising } \\
\text { capacity for effective climate } \\
\text { change-related planning and } \\
\text { management in least developed } \\
\text { countries and small island } \\
\text { developing States, including } \\
\text { focusing on women, youth and } \\
\text { local and marginalized } \\
\text { communities }\end{array}$ & $\begin{array}{l}\text { 13.b.1 Number of least developed countries and small island } \\
\text { developing States that are receiving specialized support, } \\
\text { and amount of support, including finance, technology } \\
\text { and capacity-building, for mechanisms for raising } \\
\text { capacities for effective climate change-related planning } \\
\text { and management, including focusing on women, youth } \\
\text { and local and marginalized communities }\end{array}$ & $-b$ & \\
\hline
\end{tabular}

${ }^{\mathrm{a}}$ Not relevant for Austria/already achieved, ${ }^{\mathrm{b}}$ Indicator at UN level, ${ }^{\mathrm{c}}$ Multipurpose indicator. 
The indicator systems described above cover the three pillars of sustainable development [27], also recognizing the central role of energy and climate change. Given that the scope of these indicator systems is very broad, they are not suitable for a detailed monitoring or steering of policy towards achieving the SDGs. Several indicator sets are available that focus on energy as a key element in sustainable development, most notably the Sustainable Energy Development (SED) Indicators [28] devised by the International Energy Agency (IEA) and the International Atomic Energy Agency (IEA), and the IAEA Energy Indicators for Sustainable Development [29]. These will be described in more detail below.

The SED indicators measure the progress towards "the provision of adequate energy services at affordable cost in a secure and environmentally benign manner, in conformity with social and economic development needs" [28]. IEA and IAEA propose 41 indicators for sustainable energy development that cover the whole energy system and its driving forces. This means the indicators cover primary energy supply, transformation technologies and final energy demand as well as energy intensities, the fuel mix and energy service demand. Economic and social factors (e.g., GDP, prices, population growth) affect the energy system and emissions resulting from energy consumption and energy supply.

The IEA/IAEA SED indicators have been applied to a number of countries (e.g., Lithuania [30], Cuba [31] and Mexico [32]). Depending on the challenges of energy policy and data availability, in most cases only a subset of indicators was used. Davidsdottir et al. [33] applied a set of SED indicators to Iceland, UK, USA, Sweden, Brazil and Mexico. In addition, Davidsdottir et al. [33] and Ibarrarán Viniegra et al. [34] show that the SED indicators can be communicated more easily when they are aggregated as a composite index, the so-called Sustainable Energy Index, which consists of one sub-index for each dimension of sustainable development.

Other indicator frameworks address energy security instead of sustainable energy consumption. If energy security is defined broadly, there is a strong overlap with sustainable energy development. The broad notion of energy security has economic, social and ecological aspects, albeit often with a stronger focus on economic aspects. Relevant works in this context include [16,17,35-39]. With respect to climate change, several indicator systems are also available. These indicators or indices, however, follow a less comprehensive approach, addressing mainly environmental aspects. Examples include the National Climate Indicators System Report [40], the Climate Change Performance Index [41], and the Climate Change Cooperation Index [42].

\section{The ClEP Approach}

The IEA system of Sustainable Energy Development (SED) indicators [28] provides a broad range of indicators for all levels of the energy 
system. This indicator set is the starting point for choosing relevant indicators in the demand-side sectors (residential buildings, mobility, manufacturing, services) as well as electricity and heat supply that could be applied to monitor progress in energy and climate policy at the EU or Member State levels. With respect to final energy demand, the focus is on indicators that relate to energy services because these determine welfare and economic development. The conceptual development of indicators was based on our extensive screening of available databases (e.g., Odyssee database, IEA database or Eurostat) regarding the availability of relevant indicators. Restrictions on data availability (many indicators are not available for all countries and years) co-determined the final set of indicators, i.e., we only included indicators for which at least some data for the EU Member States were available.

Data availability was acceptable for the economic and ecological dimensions but is particularly limited for the social dimension. Thus, additional information would be required to comprehensively track changes in energy use patterns and related social impacts. Gaps exist in the available data sets especially but not exclusively for the new EU Member States, where it is not possible to compile a longer time series. Moreover, for our analysis, more refined data on the use categories of final energy demand would be useful as well as more detailed information on the efficiencies of appliances (e.g., disentangling the effect of usage time from technical efficiency), non-motorised transport, investment costs, levelized costs of generation, life cycle emissions and other environmental effects such as land use and water use. Comprehensive and comparable data on energy poverty and mobility behaviour, as well as on the quality of employment at sectoral level, would also significantly improve the assessment of sustainable energy development.

In identifying indicators for sustainable energy demand, all levels of the energy system must be considered, from energy services via final energy demand to primary energy supply. Given that data on energy services are not available, proxy indicators must be specified to capture energy service demand. These proxies include transport performance, i.e., passenger and tonne kilometres for mobility as a proxy for the energy service "access to people, goods and services at different distances", the floor area of residential buildings as a proxy for "living space at a comfortable room temperature" or "lighting", population for "information, communication and other services related to consumer electronics" or "cooking” and gross value added as a proxy for energy services in the sectors manufacturing and services.

Table 2 shows the structure of the ClEP indicator framework (in Table A1 in the APPENDICES the disaggregated list of indicators is provided). For each sector, the indicators are arranged in five modules comprising context indicators, energy service indicators and energy system indicators covering the three dimensions of sustainable development. 
Context indicators include e.g., average household size, energy prices or heating degree days. For the demand-side sectors, indicators for the economic dimension include the efficiency of energy service provision (i.e., the energy service proxy divided by final energy consumption), energy costs, and patents related to energy efficiency. Economic indicators for electricity and heat supply capture transformation and distribution efficiencies, energy technology patents, and public energy R\&D expenditures. The environmental dimension covers the share of renewable energy as well as $\mathrm{CO}_{2}, \mathrm{NO}_{\mathrm{x}}$ and $\mathrm{SO}_{2}$ emissions and intensities for all sectors. For the social dimension, we developed indicators for the following sectors: residential buildings, passenger transport, and electricity and heat supply. These indicators cover i.a. the affordability of energy-related appliances and comfortable room temperature, household equipment rates with certain appliances, differences in the shares of energy costs in household expenditure by income quintiles, or the share of electric and alternative vehicles in new registrations.

In contrast to the demand-side sectors, electricity and heat supply is only indirectly related to energy services. Final energy demand and energy supply technologies determine the energy input required to supply power and heat. Thus, emissions are a result of the transformation technologies used (plant types), the fuel mix and the level of final demand. The structure of energy indicators for this sector hence deviates from the demand-side sectors. The social indicators for energy supply include the gender pay and employment gap, wage issues, and work health aspects.

For the four demand-side sectors, a set of 109 aggregate energy indicators has been assembled. These indicators have been further disaggregated to 334 indicators (e.g., the energy efficiency of electricity and heat supply can be disaggregated by plant type, and household energy efficiency can be differentiated by use category). For electricity and heat supply, we compiled a set of 21 energy indicators providing an aggregate view of the sector. These indicators were further disaggregated to about 54 indicators, differentiated by energy source and plant type. 
Table 2. List of indicators.

\begin{tabular}{|c|c|c|c|c|c|c|}
\hline \multirow{3}{*}{$\begin{array}{l}\text { Dimension } \\
\text { [of sustainable } \\
\text { development] } \\
\end{array}$} & \multicolumn{6}{|c|}{ Sector } \\
\hline & \multicolumn{5}{|c|}{ Demand Side } & \multirow{2}{*}{ Electricity \& Heat Supply } \\
\hline & Residential & Passenger Transport & Freight Transport & Manufacturing & Services & \\
\hline \multirow[t]{9}{*}{ Drivers/Context } & Housing stock & Stock of vehicles & $\begin{array}{l}\text { Stock of trucks and light } \\
\text { vehicles }\end{array}$ & & & Power plant capacity \\
\hline & FA per capita & $\begin{array}{l}\text { Modal split } \\
\text { Share of road pkm } \\
\text { Share of rail pkm }\end{array}$ & $\begin{array}{l}\text { Modal split } \\
\text { Share of road tkm } \\
\text { Share of rail tkm } \\
\text { Share of inland } \\
\text { waterways tkm } \\
\end{array}$ & Share of GVA in GDP & Share of GVA in GDP & \\
\hline & Number of $\mathrm{HH}$ & \multicolumn{2}{|c|}{$\begin{array}{l}\text { Road km } \\
\text { Rail km }\end{array}$} & \multirow{5}{*}{$\begin{array}{l}\text { Share of energy } \\
\text { intensive industry }{ }^{1} \text { in } \\
\text { FEC }\end{array}$} & & \\
\hline & HH size & \multicolumn{2}{|c|}{ Road km/rail km } & & & \\
\hline & HH income & Share of e-vehicles & & & & \\
\hline & Heating Degree Days & $\begin{array}{l}\text { Specific } \mathrm{CO}_{2} \text { emissions of car } \\
\text { stock }\end{array}$ & & & & \\
\hline & & $\begin{array}{l}\text { Specific } \mathrm{CO}_{2} \text { emissions of } \\
\text { newly registered cars }\end{array}$ & & & & \\
\hline & \multirow[t]{2}{*}{\begin{tabular}{|l} 
Energy price \\
\end{tabular}} & \multicolumn{2}{|c|}{ Energy prices } & Energy prices & Energy prices & Energy prices \\
\hline & & & & Carbon price & & Carbon price \\
\hline
\end{tabular}


Table 2. Cont.

\begin{tabular}{|c|c|c|c|c|c|c|}
\hline \multirow{3}{*}{$\begin{array}{l}\text { Dimension } \\
\text { [of sustainable } \\
\text { development] }\end{array}$} & \multicolumn{6}{|c|}{ Sector } \\
\hline & \multicolumn{5}{|c|}{ Demand Side } & \multirow{2}{*}{ Electricity \& Heat Supply } \\
\hline & Residential & Passenger Transport & Freight Transport & Manufacturing & Services & \\
\hline \multirow[t]{6}{*}{$\begin{array}{l}\text { Energy Service } \\
\text { Proxies }\end{array}$} & $\begin{array}{l}\text { Well-tempered living } \\
\text { space: FA }\end{array}$ & \multirow[t]{6}{*}{ Mobility: pkm } & \multirow[t]{6}{*}{ Transport of goods: tkm } & \multirow[t]{6}{*}{ GVA } & \multirow[t]{6}{*}{ GVA } & \\
\hline & Illumination: $\mathrm{HH}$ & & & & & \\
\hline & Warm water: CAP & & & & & \\
\hline & Cooking: HH & & & & & \\
\hline & $\begin{array}{l}\text { Communication/Entertain } \\
\text { ment: } \mathrm{HH}\end{array}$ & & & & & \\
\hline & Other: $\mathrm{HH}$ & & & & & \\
\hline \multirow[t]{7}{*}{ Economic } & \multirow{2}{*}{$\begin{array}{l}\text { Efficiency of residential } \\
\text { sector (HH/FEC) }\end{array}$} & \multirow{2}{*}{$\begin{array}{l}\text { Efficiency of passenger } \\
\text { transport }(\mathrm{pkm} / \mathrm{FEC})\end{array}$} & \multirow{2}{*}{$\begin{array}{l}\text { Efficiency of freight } \\
\text { transport (tkm/FEC) }\end{array}$} & \multirow{2}{*}{$\begin{array}{l}\text { Efficiency of } \\
\text { manufacturing }\end{array}$} & \multirow{2}{*}{$\begin{array}{l}\text { Efficiency of service } \\
\text { sector }\end{array}$} & Distribution efficiency \\
\hline & & & & & & $\begin{array}{l}\text { Transformation } \\
\text { efficiency }\end{array}$ \\
\hline & \multirow[t]{2}{*}{ FEC } & \multirow[t]{2}{*}{ FEC } & \multirow[t]{2}{*}{ FEC } & \multirow[t]{2}{*}{ FEC } & \multirow[t]{2}{*}{ FEC } & $\begin{array}{l}\text { Transformation input } \\
\text { (TI) }\end{array}$ \\
\hline & & & & & & $\begin{array}{l}\text { Transformation output } \\
\text { (TO) }\end{array}$ \\
\hline & $\begin{array}{l}\text { Share of energy } \\
\text { expenditure in household } \\
\text { expenditure }\end{array}$ & $\begin{array}{l}\text { Share of transport } \\
\text { expenditure in household } \\
\text { expenditure }\end{array}$ & & Share of costs & Share of costs & \\
\hline & $\begin{array}{l}\text { Public R\&D expenditures } \\
\text { energy efficiency } \\
\text { buildings }\end{array}$ & \multicolumn{2}{|c|}{ Public R\&D expenditures transport } & $\begin{array}{l}\text { Public R\&D expenditures } \\
\text { energy efficiency } \\
\text { industry }\end{array}$ & & $\begin{array}{l}\text { Public energy R\&D } \\
\text { expenditures }\end{array}$ \\
\hline & $\begin{array}{l}\text { Applied patents energy } \\
\text { efficiency buildings }\end{array}$ & \multicolumn{2}{|c|}{ Applied patents energy efficiency transport } & $\begin{array}{l}\text { Applied patents } \\
\text { mitigation industry }\end{array}$ & & $\begin{array}{l}\text { Applied energy } \\
\text { technology patents }\end{array}$ \\
\hline
\end{tabular}


Table 2. Cont.

\begin{tabular}{|c|c|c|c|c|c|c|}
\hline \multirow{3}{*}{$\begin{array}{l}\text { Dimension } \\
\text { [of sustainable } \\
\text { development] }\end{array}$} & \multicolumn{6}{|c|}{ Sector } \\
\hline & \multicolumn{5}{|c|}{ Demand Side } & \multirow{2}{*}{ Electricity \& Heat Suppl] } \\
\hline & Residential & Passenger Transport & Freight Transport & Manufacturing & Services & \\
\hline \multirow[t]{7}{*}{ Ecological } & Share of RES & Share of RES & Share of RES & Share of RES & Share of RES & Share of RES in TI \\
\hline & $\mathrm{CO}_{2}$ emissions & $\mathrm{CO}_{2}$ emissions & $\mathrm{CO}_{2}$ emissions & $\mathrm{CO}_{2}$ emissions & $\mathrm{CO}_{2}$ emissions & $\mathrm{CO}_{2}$ emissions \\
\hline & $\mathrm{NO}_{\mathrm{x}}$ emissions & $\mathrm{NO}_{\mathrm{x}}$ emissions & $\mathrm{NO}_{\mathrm{x}}$ emissions & $\mathrm{NO}_{\mathrm{x}}$ emissions & $\mathrm{NO}_{\mathrm{x}}$ emissions & $\mathrm{NO}_{\mathrm{x}}$ emissions \\
\hline & $\mathrm{SO}_{2}$ emissions & $\mathrm{SO}_{2}$ emissions & $\mathrm{SO}_{2}$ emissions & $\mathrm{SO}_{2}$ emissions & $\mathrm{SO}_{2}$ emissions & $\mathrm{SO}_{2}$ emissions \\
\hline & $\mathrm{CO}_{2}$ efficiency of $\mathrm{FEC}$ & $\mathrm{CO}_{2}$ efficiency of $\mathrm{FEC}$ & $\mathrm{CO}_{2}$ efficiency of $\mathrm{FEC}$ & $\mathrm{CO}_{2}$ efficiency of $\mathrm{FEC}$ & $\mathrm{CO}_{2}$ efficiency of $\mathrm{FEC}$ & $\mathrm{CO}_{2}$ efficiency of TI \\
\hline & $\mathrm{NO}_{\mathrm{x}}$ efficiency of FEC & $\mathrm{NO}_{\mathrm{x}}$ efficiency of FEC & $\mathrm{NO}_{\mathrm{x}}$ efficiency of FEC & $\mathrm{NO}_{\mathrm{x}}$ efficiency of $\mathrm{FEC}$ & $\mathrm{NO}_{\mathrm{x}}$ efficiency of FEC & $\mathrm{NO}_{\mathrm{x}}$ efficiency of $\mathrm{TI}$ \\
\hline & $\mathrm{SO}_{2}$ efficiency of $\mathrm{FEC}$ & $\mathrm{SO}_{2}$ efficiency of FEC & $\mathrm{SO}_{2}$ efficiency of $\mathrm{FEC}$ & $\mathrm{SO}_{2}$ efficiency of FEC & $\mathrm{SO}_{2}$ efficiency of FEC & $\mathrm{SO}_{2}$ efficiency of TI \\
\hline \multirow[t]{6}{*}{ Social } & $\begin{array}{l}\text { Persons who cannot } \\
\text { afford a telephone }\end{array}$ & $\begin{array}{l}\text { New registrations of } \\
\text { passenger cars }\end{array}$ & & & & Low-wage earners \\
\hline & $\begin{array}{l}\text { Persons who cannot } \\
\text { afford a colour TV }\end{array}$ & $\begin{array}{l}\text { New registrations of electric } \\
\text { passenger cars }\end{array}$ & & & & Median hourly earnings \\
\hline & $\begin{array}{l}\text { Persons who cannot } \\
\text { afford a computer }\end{array}$ & $\begin{array}{l}\text { New registrations of } \\
\text { passenger cars w alternative } \\
\text { drives }\end{array}$ & & & & Temporary contracts \\
\hline & $\begin{array}{l}\text { Persons who cannot } \\
\text { afford a washing machine }\end{array}$ & $\begin{array}{l}\text { Level of difficulty to access } \\
\text { public transport }\end{array}$ & & & & $\begin{array}{l}\text { Incidence rate of fatal } \\
\text { accidents at work }\end{array}$ \\
\hline & $\begin{array}{l}\text { Persons who cannot } \\
\text { afford internet connection } \\
\text { for personal use at home }\end{array}$ & $\begin{array}{l}\text { Persons who cannot afford a } \\
\text { car }\end{array}$ & & & & $\begin{array}{l}\text { Flexibility of the work } \\
\text { schedule }\end{array}$ \\
\hline & $\begin{array}{l}\text { Population unable to keep } \\
\text { home adequately warm } \\
\text { by poverty status }\end{array}$ & & & & & Gender pay gap \\
\hline
\end{tabular}


Table 2. Cont.

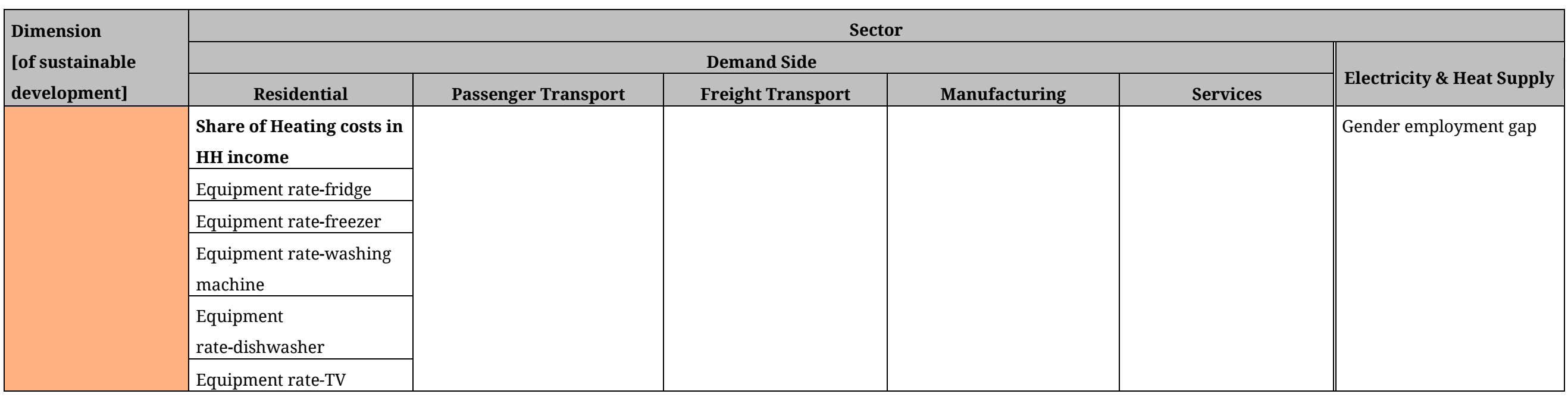

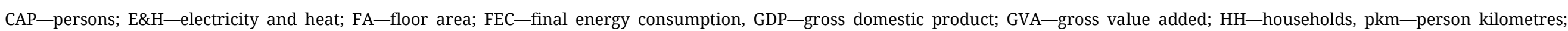

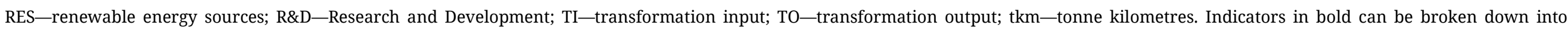
sub-indicators.

${ }^{1}$ Energy intensive industry here includes chemical sector, primary metals production, non-metallic minerals production, paper production, and wood production. 


\section{AVAILABLE DATA SOURCES FOR THE CLEP INDICATORS}

In order to compile the indicators for the EU Member States, several databases need to be deployed. Data are available from the following databases:

- Odyssee database [43]: data on energy service proxies (floor area of dwellings, number of households, passenger and freight transport performance, gross value added of the manufacturing and service sectors), and the related efficiency data, information on the different capital stocks and equipment rates, sectoral shares of renewable energy sources and final energy consumption by energy source;

- The European Environment Agency's database [44]: $\mathrm{CO}_{2}$ emissions of newly registered vehicles;

- IEA database [45-47]: transformation input and output by energy source, plant capacities, energy prices and sectoral public energy expenditure;

- UNFCCC National Inventories [1]: GHG emission data;

- Eurostat database [48-52]: household income and expenditures, social indicators (except for equipment rates);

- OECD database [53]: patent data;

- $E E X$ [54]: data on carbon prices.

We aimed at identifying official data sources for the indicators that are available for all (or at least for the majority of) the EU Member States (like the Eurostat database, the OECD database, the EEA database or the UNFCCC National Inventories). Especially with respect to energy services and stocks, relevant data was not available from official statistical sources, so we relied on the Odyssee database in this regard. The latter provides information on final energy consumption by end-use category, the underlying drivers of energy demand, disaggregated energy efficiencies and $\mathrm{CO}_{2}$ related indicators; data are provided by national institutions (e.g., energy agencies or statistical organizations) from all EU countries as well as Norway, Switzerland and Serbia. Moreover, we suggest using information on energy prices and sectoral public energy expenditure from the IEA database due to better data availability as compared to the Eurostat database. The detailed list of data sources for the individual indicators can be found in Table A2 and Table A3 in the APPENDICES.

\section{A GLANCE AT INTERACTIONS BETWEEN DIMENSIONS AND INDICATORS}

Given the importance of accounting for interactions between SDGs and sub-targets, we highlighted the relationship between the energy service focused ClEP indicators and the broader context of the SDGs. For example, when integrating the social dimension into the climate and energy policy indicator set, the focus is on the quality of employment on the energy supply side, whereas the focus is on daily conduct of life 
practices in private households on the energy demand side [55]. We identified cross-cutting issues that are relevant for all areas and at the same time highlight the relation to some other SDGs: gender equality [56,57] and gender equity [58] — both for energy supply and energy demand [59], improving the quality of employment (on the energy supply side) and respectively quality of life (on the energy demand side), as well as participation on the energy supply side or inclusion on the energy demand side. Reflecting the outcomes makes the multidimensionality and the ambivalences of the different dimensions visible, in particular as a consequence of the inclusion of the social dimension. For example, an increase in physical assets such as household appliances and vehicles may mean a reduction of social inequality and/ or an increase in mobility, but at the same time can have negative impacts on the environment-depending on the choice of technologies and/or fuels. This example reveals the multiple uncertainties associated with attempts to predict how particular future trends affect everyday life, consumption and mobility behaviors.

Table 3 exemplifies interactions between different indicators and goals. Trade-offs between different SDGs become visible. Depending on the underlying assumptions, different development paths are conceivable, with varying impacts on the environment as well as economic and social development.

Table 3. Interdependence table of social indicators and their impact on the SDGs.

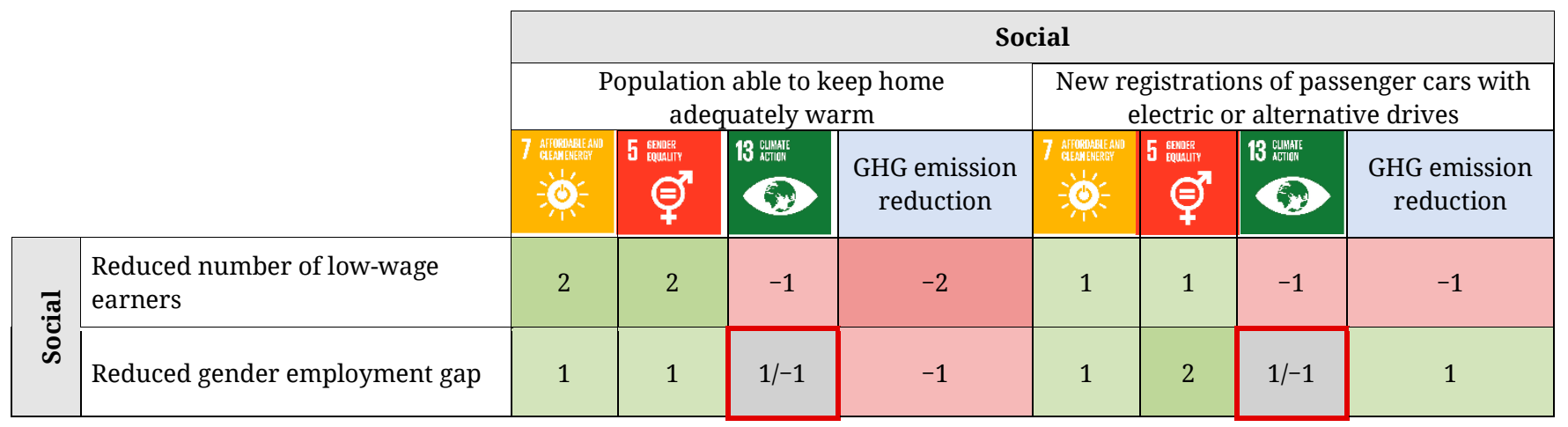

The evaluation of interactions follows Nilsson et al. [5] and ranges from -3 to +3 : -3 denotes cancelling targets while +3 denotes indivisible targets.

Table 3 shows that an increase in the number of low-wage earners implies a considerable change in material and immaterial deprivation. This may entail, for instance, an increase in the proportion of the population unable to sufficiently heat their home or a lower number of newly registered electric cars and cars with alternative drive systems. This would negatively impact the achievement of SDG 7 "Ensure access to affordable, reliable, sustainable and modern energy for all”. At the same time, this raises the question of whether the purchase of a more energy-efficient car would replace an existing conventional vehicle or if it would add an additional car to the household's stock. The latter may 
possibly mean an increase in mobility, in particular of women and young adults in the household, since they are often the users of the additional car, which in turn would have a negative effect from an environmental perspective and respectively SDG 13 "Take urgent action to combat climate change and its impacts”. By contrast, if increased mobility implies that women drive more, it would positively affect SDG 5 "Achieve gender equality and empower all women and girls" by increasing mobility options and the opportunities for participation in the labour force or other social activities. These different lines of argumentation illustrate that, depending on the assumptions made or the focus chosen, the effects would need to be judged differently.

These observations point to the comprehensive political and social challenges, both regionally and globally, of finding and deploying holistic and coherent measures that address the complex interactions between the SDGs in unison. It should be noted that all SDGs are "integrated and indivisible" and therefore should be considered equal [24]. Focusing on individual goals and ignoring others creates the risk of overlooking relevant side effects and failing to recognise and make use of potential synergies [2].

Added to this is the problem of data availability mentioned before. The lack of data can distort the picture, if indicators for relevant impacts and policy areas are missing.

\section{CONCLUSIONS}

The UN SDGs and the Paris Climate Agreement both imply ambitious (long-term) targets that can only be met with a fundamental restructuring of economic and social systems. In this context, monitoring of progress towards achievement of goals is essential and requires thorough measurement systems.

The complexity calls for indicator systems instead of single indicators. Although the list of indicators proposed to monitor the 17 SDGs and the corresponding 169 targets is already very comprehensive, more detailed indicator sets for individual SDGs are required for the monitoring and steering of policy. Moreover, the General Assembly of the UN proposed complementing the UN indicator set with operational indicators at the national and regional levels to be developed by the countries and which would reflect their particular circumstances [24]. Against this background, we propose a set of indicators that allow monitoring of progress towards energy and climate policy targets at the EU and Member State levels.

We combine the energy service perspective with research on sustainable energy development indicators and apply this approach in the broader context of the SDGs. Furthermore, we put particular emphasis on the consideration of the social dimension and the development of respective indicators. The proposed sustainable energy indicators cover the three dimensions of sustainable development. As for 
the SDGs, interactions (i.e., synergies and conflicts) between the different target dimensions and the corresponding indicators need to be carefully considered.

As shown in Kettner et al. [60], a composite index can be used to complement comprehensive indicator systems such as the one at hand. Composite indices are a common method used to condense multifaceted information and to improve the communicability of results. In Kettner et al. [60], this approach was applied to assess the sustainable energy development in nine EU countries using a subset of indicators. One group of composite indices focussed on the dimension of sustainable development and the other on the sectoral disaggregation, providing concise information on trends in each country. Recently, composite indices that summarise global progress while considering possible conflicts and trade-offs between individual targets and indicators have been developed based on a Goal Programming Model [61,62] or a Multidimensional Synthesis of Indicators approach [63]. Applying these methods to our indicator set would presumably deliver valuable insights but would require better data availability.

Given the complexity of the issue and the gaps in data availability/adequate indicators, it is challenging to interpret certain observable trends. For instance, an increase in electric cars can have both beneficial and detrimental effects on the environment, depending on whether these cars are substitutes for fossil-fuel-powered cars or additional vehicles. By contrast, an increasing number of vehicles can enhance mobility and thereby be interpreted as an improvement in the social dimension of sustainable development. However, the net effect on mobility is again impossible to assess because no data on non-motorised transport are available and particularly due to the complex underlying interactions. This needs to be kept in mind when using the indicator system for policy analysis. The analysis highlights the importance of taking into account the multitude of interactions between different sustainable development targets. The comprehensive assessment helps prevent perverse outcomes and contributes to fully utilising the potential for achieving synergistic outcomes for other targets. Applying advanced statistical methods such as principal component analysis would shed light on correlations between the individual indicators. This would require, however, further advances in data and indicator availability for a larger number of EU Member States because many indicators currently are available only for a small number of countries and individual years. 


\section{AUTHOR CONTRIBUTIONS}

All authors jointly designed the study and developed the indicator framework. All authors contributed to writing the paper.

\section{CONFLICTS OF INTEREST}

The authors declare that there is no conflict of interest.

\section{FUNDING}

This research was funded by the Climate and Energy Funds within the Austrian Climate Research Programme (ACRP).

\section{ACKNOWLEDGMENTS}

We would like to thank Katharina Köberl and Susanne Markytan for excellent research assistance. 


\section{APPENDICES}

Table A1. Detailed list of indicators.

\begin{tabular}{|c|c|c|c|c|c|c|}
\hline \multirow{3}{*}{$\begin{array}{l}\text { Dimension (of } \\
\text { sustainable } \\
\text { development) }\end{array}$} & \multicolumn{6}{|c|}{ Sector } \\
\hline & \multicolumn{5}{|c|}{ Demand Side } & \multirow{2}{*}{ Electricity \& Heat Supply } \\
\hline & Residential & Passenger Transport & Freight Transport & Manufacturing & Services & \\
\hline \multirow[t]{2}{*}{ Drivers/Context } & Housing stock & $\begin{array}{l}\text { Stock of vehicles } \\
\text { - Vehicles } \\
\text { - } \text { Diesel-driven cars } \\
\text { - Gasoline-driven cars } \\
\text { - Gas-driven cars } \\
\text { - Electric-driven cars } \\
\text { - Motor cycles } \\
\text { - Busses }\end{array}$ & $\begin{array}{l}\text { Stock of trucks and light } \\
\text { vehicles }\end{array}$ & & & $\begin{array}{l}\text { Power plant capacity } \\
\text { - Capacity power plants } \\
\text { - Capacity nuclear plants } \\
\text { - Capacity hydro plants } \\
\text { - Capacity geothermal plants } \\
\text { - Capacity solar PV plants } \\
\text { - Capacity solar thermal plants } \\
\text { - Capacity combustible plants } \\
\text { - Capacity other sources plants }\end{array}$ \\
\hline & FA per capita & $\begin{array}{l}\text { Modal split } \\
\text { - Share of road pkm } \\
\text { - Share of rail pkm }\end{array}$ & $\begin{array}{l}\text { Modal split } \\
\text { - Share of road tkm } \\
\text { - Share of rail tkm } \\
\text { - Share of inland } \\
\text { waterways tkm }\end{array}$ & Share of GVA in GDP & Share of GVA in GDP & \\
\hline
\end{tabular}


Table A1. Cont.

\begin{tabular}{|c|c|c|c|c|c|c|}
\hline \multirow{3}{*}{$\begin{array}{l}\text { Dimension (of } \\
\text { sustainable } \\
\text { development) }\end{array}$} & \multicolumn{6}{|c|}{ Sector } \\
\hline & \multicolumn{5}{|c|}{ Demand Side } & \multirow{2}{*}{ Electricity \& Heat Supply } \\
\hline & Residential & Passenger Transport & Freight Transport & Manufacturing & Services & \\
\hline & Number of $\mathrm{HH}$ & \multicolumn{2}{|c|}{$\begin{array}{l}\text { Road km } \\
\text { Rail km }\end{array}$} & \multirow{5}{*}{$\begin{array}{l}\text { Share of energy intensive industry }{ }^{1} \text { in } \\
\text { FEC } \\
\text { - Share of energy intensive industry in } \\
\text { FEC } \\
\text { - Share of energy intensive industry in } \\
\text { FEC coal } \\
\text { - Share of energy intensive industry in } \\
\text { FEC gas } \\
\text { - Share of energy intensive industry in } \\
\text { FEC oil } \\
\text { - Share of energy intensive industry in } \\
\text { FEC biomass } \\
\text { - Share of energy intensive industry in } \\
\text { FEC electricity } \\
\text { - Share of energy intensive industry in } \\
\text { FEC heat }\end{array}$} & & \\
\hline & HH size & \multicolumn{2}{|c|}{ Road km/rail km } & & & \\
\hline & $\begin{array}{l}\text { HH income } \\
\text { - } \text { Quintile } 1 \\
\text { - } \text { Quintile 2 } \\
\text { - } \text { Quintile } 3 \\
\text { - Quintile } 4 \\
\text { - } \text { Quintile } 5 \\
\end{array}$ & Share of e-vehicles & & & & \\
\hline & $\begin{array}{l}\text { Heating Degree } \\
\text { Days }\end{array}$ & $\begin{array}{l}\text { Specific } \mathrm{CO}_{2} \text { emissions of } \\
\text { car stock }\end{array}$ & & & & \\
\hline & & $\begin{array}{l}\text { Specific } \mathrm{CO}_{2} \text { emissions of } \\
\text { newly registered cars }\end{array}$ & & & & \\
\hline & $\begin{array}{l}\text { Energy prices } \\
\text { - Gas price } \\
\text { households } \\
\text { - Oil price } \\
\text { households } \\
\text { - Electricity price } \\
\text { households }\end{array}$ & \multicolumn{2}{|c|}{$\begin{array}{l}\text { Energy prices } \\
\text { - Gasoline price } \\
\text { - Diesel price }\end{array}$} & $\begin{array}{l}\text { Energy prices } \\
\text { - Gas price industry } \\
\text { - Heavy fuel oil price industry } \\
\text { - Light fuel oil price industry } \\
\text { - Coal price industry } \\
\text { - Electricity price industry }\end{array}$ & $\begin{array}{l}\text { Energy prices } \\
\text { - Gas price } \\
\text { - Oil price } \\
\text { - Electricity price }\end{array}$ & $\begin{array}{l}\text { Energy prices } \\
\text { - Gas price energy plants } \\
\text { - Oil price energy plants } \\
\text { - Coal price energy plants }\end{array}$ \\
\hline & & & & Carbon price & & Carbon price \\
\hline
\end{tabular}


Table A1. Cont.

\begin{tabular}{|c|c|c|c|c|c|c|}
\hline \multirow{3}{*}{$\begin{array}{l}\text { Dimension (of } \\
\text { sustainable } \\
\text { development) }\end{array}$} & \multicolumn{6}{|c|}{ Sector } \\
\hline & \multicolumn{5}{|c|}{ Demand Side } & \multirow{2}{*}{ Electricity \& Heat Supply } \\
\hline & Residential & Passenger Transport & Freight Transport & Manufacturing & Services & \\
\hline \multirow{7}{*}{$\begin{array}{l}\text { Energy Service } \\
\text { Proxies }\end{array}$} & Well-tempered & \multirow{7}{*}{$\begin{array}{l}\text { Mobility } \\
\text { - Pkm total } \\
\text { - Pkm road } \\
\text { - Pkm rail }\end{array}$} & \multirow{7}{*}{$\begin{array}{l}\text { Transport of goods } \\
\text { - Tkm total } \\
\text { - Tkm road } \\
\text { - Tkm rail } \\
\text { - Tkm inland } \\
\text { waterways }\end{array}$} & \multirow{7}{*}{$\begin{array}{l}\text { GVA } \\
\text { - GVA industry } \\
\text { - GVA chemical sector } \\
\text { - GVA primary metals production } \\
\text { - GVA non-metallic minerals production } \\
\text { - GVA wood sector } \\
\text { - GVA paper sector }\end{array}$} & \multirow[t]{7}{*}{ GVA } & \\
\hline & living space: FA & & & & & \\
\hline & Illumination: $\mathrm{HH}$ & & & & & \\
\hline & Warm water: CAP & & & & & \\
\hline & Cooking: $\mathrm{HH}$ & & & & & \\
\hline & $\begin{array}{l}\text { Communication/Ent } \\
\text { ertainment: } \mathrm{HH}\end{array}$ & & & & & \\
\hline & Other: HH & & & & & \\
\hline Economic & $\begin{array}{l}\text { Efficiency of } \\
\text { residential sector } \\
\text { (HH/FEC) } \\
\text { - } \text { Household/FEC } \\
\text { - } \text { Household/FEC } \\
\text { coal } \\
\text { - } \text { Household/FEC } \\
\text { gas } \\
\text { - Household/FEC } \\
\text { oil } \\
\text { - Household/FEC } \\
\text { biomass } \\
\text { - Household/FEC } \\
\text { electricity } \\
\text { Household/FEC } \\
\text { heat }\end{array}$ & $\begin{array}{l}\text { Efficiency of passenger } \\
\text { transport (pkm/FEC) } \\
\text { - } \mathrm{Pkm} / \mathrm{FEC} \\
\text { - } \mathrm{Pkm} / \mathrm{FEC} \text { gasoline } \\
\text { - } \mathrm{Pkm} / \mathrm{FEC} \text { diesel } \\
\text { - } \mathrm{Pkm} / \mathrm{FEC} \text { gas } \\
\text { - } \mathrm{Pkm} / \mathrm{FEC} \text { jet fuel } \\
\text { - } \mathrm{Pkm} / \mathrm{FEC} \text { electricity } \\
\text { - } \mathrm{Pkm} / \mathrm{FEC} \text { biofuels }\end{array}$ & $\begin{array}{l}\text { Efficiency of freight } \\
\text { transport (tkm/FEC) } \\
\text { - Tkm/FEC } \\
\text { - Tkm/FEC diesel } \\
\text { - Tkm/FEC electricity } \\
\text { - Tkm/FEC biofuels }\end{array}$ & $\begin{array}{l}\text { Efficiency of manufacturing } \\
\text { - GVA/FEC } \\
\text { - GVA/FEC coal } \\
\text { - GVA/FEC gas } \\
\text { - GVA/FEC oil } \\
\text { - GVA/FEC biomass } \\
\text { - GVA/FEC electricity } \\
\text { - GVA/FEC heat }\end{array}$ & $\begin{array}{l}\text { Efficiency of service } \\
\text { sector } \\
\text { - GVA/FEC } \\
\text { - GVA/FEC coal } \\
\text { - GVA/FEC gas } \\
\text { - GVA/FEC oil } \\
\text { - GVA/FEC biomass } \\
\text { - GVA/FEC } \\
\text { electricity } \\
\text { - GVA/FEC heat }\end{array}$ & $\begin{array}{l}\text { Distribution efficiency } \\
\text { - Distribution efficiency } \\
\text { - Distribution efficiency } \\
\text { electricity } \\
\text { - Distribution efficiency heat }\end{array}$ \\
\hline
\end{tabular}


Table A1. Cont.

\begin{tabular}{|c|c|c|c|c|c|c|}
\hline \multirow{3}{*}{$\begin{array}{l}\text { Dimension (of } \\
\text { sustainable } \\
\text { development) }\end{array}$} & \multicolumn{6}{|c|}{ Sector } \\
\hline & \multicolumn{5}{|c|}{ Demand Side } & \multirow{2}{*}{ Electricity \& Heat Supply } \\
\hline & Residential & Passenger Transport & Freight Transport & Manufacturing & Services & \\
\hline & $\begin{array}{l}\text { Efficiency of } \\
\text { space heating } \\
\text { (FA/FEC) } \\
\text { - FA/FEC space } \\
\text { heating } \\
\text { - FA/FEC coal } \\
\text { space heating } \\
\text { - FA/FEC gas space } \\
\text { heating } \\
\text { - FA/FEC oil space } \\
\text { heating } \\
\text { - FA/FEC biomass } \\
\text { space heating } \\
\text { - FA/FEC electricity } \\
\text { space heating } \\
\text { - FA/FEC heat } \\
\text { space heating }\end{array}$ & & & $\begin{array}{l}\text { Efficiency of chemical sector } \\
(\text { GVA/FEC }) \\
\text { - GVA/FEC chemical sector } \\
\text { - GVA/FEC coal chemical sector } \\
\text { - GVA/FEC gas chemical sector } \\
\text { - GVA/FEC oil chemical sector } \\
\text { - GVA/FEC biomass chemical sector } \\
\text { - GVA/FEC electricity chemical sector } \\
\text { - GVA/FEC heat chemical sector }\end{array}$ & & $\begin{array}{l}\text { Transformation efficiency (TO/ } \\
\text { TI) } \\
\text { - Transformation efficiency } \\
\text { - Transformation efficiency } \\
\text { coal plants } \\
\text { - Transformation efficiency gas } \\
\text { plants } \\
\text { - Transformation efficiency oil } \\
\text { plants } \\
\text { - Transformation efficiency } \\
\text { waste plants } \\
\text { - Transformation efficiency } \\
\text { renewables plants }\end{array}$ \\
\hline
\end{tabular}


Table A1. Cont.

\begin{tabular}{|c|c|c|c|c|c|c|}
\hline \multirow{3}{*}{$\begin{array}{l}\text { Dimension (of } \\
\text { sustainable } \\
\text { development) }\end{array}$} & \multicolumn{6}{|c|}{ Sector } \\
\hline & \multicolumn{5}{|c|}{ Demand Side } & \multirow{2}{*}{ Electricity \& Heat Supply } \\
\hline & Residential & Passenger Transport & Freight Transport & Manufacturing & Services & \\
\hline & $\begin{array}{l}\text { Efficiency of warm } \\
\text { water } \\
\text { (CAP/FEC) } \\
\text { - CAP/FEC warm } \\
\text { water } \\
\text { - CAP/FEC coal } \\
\text { warm water } \\
\text { - CAP/FEC oil } \\
\text { warm water } \\
\text { - AP/FEC gas warm } \\
\text { water } \\
\text { - CAP/FEC biomass } \\
\text { warm water } \\
\text { - CAP/FEC } \\
\text { electricity warm } \\
\text { water } \\
\text { - CAP/FEC heat } \\
\text { warm water }\end{array}$ & & & $\begin{array}{l}\text { Efficiency of primary metals sector } \\
(\text { GVA/FEC }) \\
\text { - GVA/FEC primary metals sector } \\
\text { - GVA/FEC coal primary metals sector } \\
\text { - GVA/FEC gas primary metals sector } \\
\text { - GVA/FEC oil primary metals sector } \\
\text { - GVA/FEC biomass primary metals } \\
\text { sector } \\
\text { - GVA/FEC electricity primary metals } \\
\text { sector } \\
\text { - GVA/FEC heat primary metals sector }\end{array}$ & & \\
\hline
\end{tabular}


Table A1. Cont.

\begin{tabular}{|c|c|c|c|c|c|c|}
\hline \multirow{3}{*}{$\begin{array}{l}\text { Dimension (of } \\
\text { sustainable } \\
\text { development) }\end{array}$} & \multicolumn{6}{|c|}{ Sector } \\
\hline & \multicolumn{5}{|c|}{ Demand Side } & \multirow{2}{*}{ Electricity \& Heat Supply } \\
\hline & Residential & Passenger Transport & Freight Transport & Manufacturing & Services & \\
\hline & $\begin{array}{l}\text { Efficiency of cooking } \\
\text { (CAP/FEC) } \\
\text { - CAP/FEC cooking } \\
\text { - } \text { CAP/FEC coal } \\
\text { cooking } \\
\text { - CAP/FEC gas } \\
\text { cooking } \\
\text { - CAP/FEC biomass } \\
\text { cooking } \\
\text { CAP/FEC } \\
\text { electricity } \\
\text { cooking }\end{array}$ & & & $\begin{array}{l}\text { Efficiency of non- metallic minerals } \\
\text { production (GVA/FEC) } \\
\text { - GVA/FEC non-metallic minerals } \\
\text { production } \\
\text { - GVA/FEC coal non-metallic minerals } \\
\text { production } \\
\text { - GVA/FEC gas non-metallic minerals } \\
\text { production } \\
\text { - GVA/FEC oil non-metallic minerals } \\
\text { production } \\
\text { - GVA/FEC biomass non-metallic } \\
\text { minerals production } \\
\text { - GVA/FEC electricity non-metallic } \\
\text { minerals production } \\
\text { - GVA/FEC heat non-metallic minerals } \\
\text { production }\end{array}$ & & \\
\hline
\end{tabular}


Table A1. Cont.

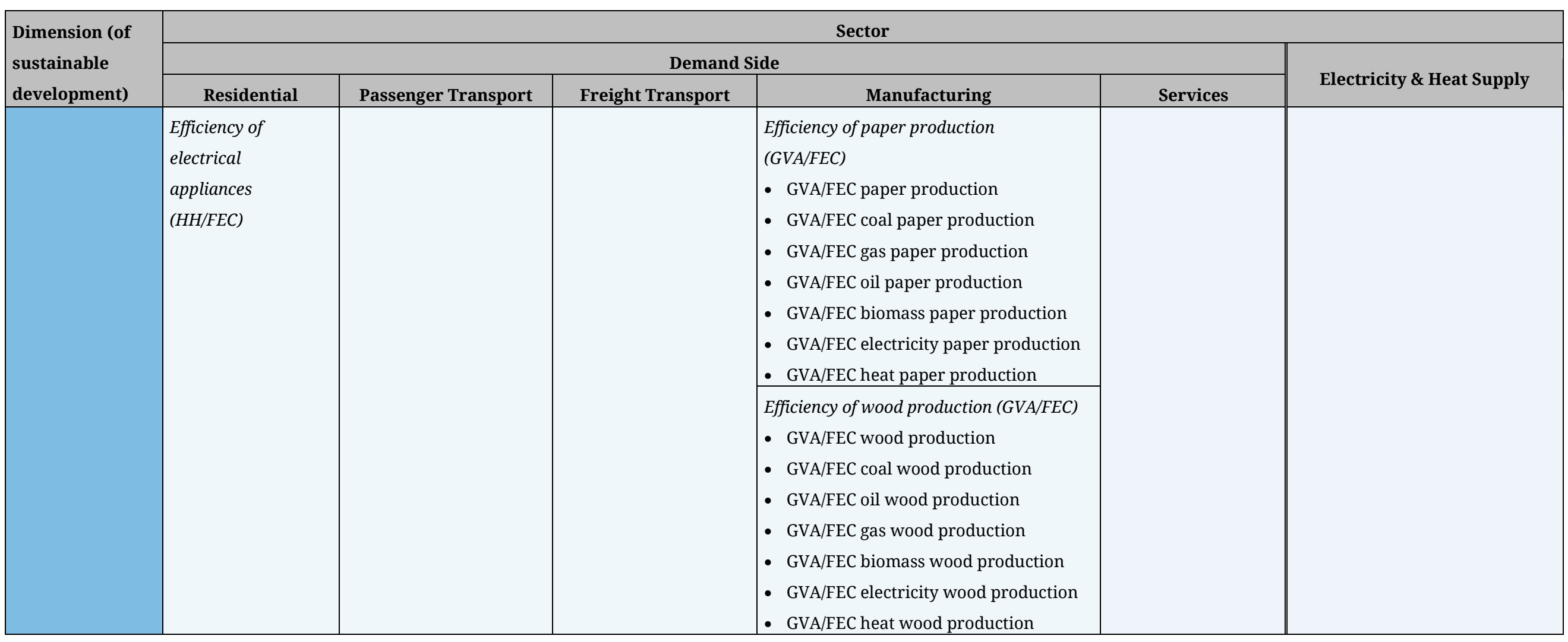


Table A1. Cont.

\begin{tabular}{|c|c|c|c|c|c|c|}
\hline \multirow{3}{*}{$\begin{array}{l}\text { Dimension (of } \\
\text { sustainable } \\
\text { development) }\end{array}$} & \multicolumn{6}{|c|}{ Sector } \\
\hline & \multicolumn{5}{|c|}{ Demand Side } & \multirow{2}{*}{ Electricity \& Heat Supply } \\
\hline & Residential & Passenger Transport & Freight Transport & Manufacturing & Services & \\
\hline & $\begin{array}{l}\text { FEC } \\
\text { - FEC } \\
\text { - FEC coal } \\
\text { - FEC gas } \\
\text { - FEC oil } \\
\text { - FEC biomass } \\
\text { - FEC electricity } \\
\text { - FEC heat } \\
\end{array}$ & \multirow[t]{2}{*}{$\begin{array}{l}\text { FEC } \\
\text { - FEC } \\
\text { - FEC gasoline } \\
\text { - FEC diesel } \\
\text { - FEC gas } \\
\text { - FEC jet fuel } \\
\text { - FEC electricity } \\
\text { - FEC biofuels }\end{array}$} & \multirow[t]{2}{*}{$\begin{array}{l}\text { FEC } \\
\text { - } \text { FEC } \\
\text { - } \text { FEC diesel } \\
\text { - } \quad \text { FEC electricity } \\
\text { - } \quad \text { FEC biofuels }\end{array}$} & $\begin{array}{l}\text { FEC } \\
\text { - FEC } \\
\text { - FEC coal } \\
\text { - FEC gas } \\
\text { - FEC oil } \\
\text { - FEC biomass } \\
\text { - FEC electricity } \\
\text { - FEC heat } \\
\end{array}$ & \multirow[t]{2}{*}{$\begin{array}{l}\text { FEC } \\
\text { - FEC } \\
\text { - FEC coal } \\
\text { - FEC gas } \\
\text { - FEC oil } \\
\text { - FEC biomass } \\
\text { - FEC electricity } \\
\text { - FEC heat }\end{array}$} & $\begin{array}{l}\text { Transformation input } \\
\text { - TI } \\
\text { - TI coal } \\
\text { - TI gas } \\
\text { - TI oil } \\
\text { - TI waste } \\
\text { - TI renewables } \\
\end{array}$ \\
\hline & $\begin{array}{l}\text { FEC space } \\
\text { heating } \\
\text { - FEC space } \\
\text { heating } \\
\text { - } \text { FEC coal space } \\
\text { heating } \\
\text { - FEC gas space } \\
\text { heating } \\
\text { - FEC oil space } \\
\text { heating } \\
\text { - FEC biomass } \\
\text { space heating } \\
\text { - FEC electricity } \\
\text { space heating } \\
\text { - FEC heat space } \\
\text { heating }\end{array}$ & & & $\begin{array}{l}\text { FEC chemical sector } \\
\text { - FEC chemical sector } \\
\text { - FEC coal chemical sector } \\
\text { - FEC gas chemical sector } \\
\text { - FEC oil chemical sector } \\
\text { - FEC biomass chemical sector } \\
\text { - FEC electricity chemical sector } \\
\text { - FEC heat chemical sector }\end{array}$ & & $\begin{array}{l}\text { Transformation output } \\
\text { TO } \\
\text { - TO coal plants } \\
\text { - TO gas plants } \\
\text { - TO oil plants } \\
\text { - TO waste plants } \\
\text { - TO renewable plants }\end{array}$ \\
\hline
\end{tabular}


Table A1. Cont.

\begin{tabular}{|c|c|c|c|c|c|c|}
\hline \multirow{3}{*}{$\begin{array}{l}\text { Dimension (of } \\
\text { sustainable } \\
\text { development) }\end{array}$} & \multicolumn{6}{|c|}{ Sector } \\
\hline & \multicolumn{5}{|c|}{ Demand Side } & \multirow{2}{*}{ Electricity \& Heat Supply } \\
\hline & Residential & Passenger Transport & Freight Transport & Manufacturing & Services & \\
\hline & $\begin{array}{l}\text { FEC warm water } \\
\text { - FEC warm water } \\
\text { - FEC coal warm } \\
\text { water } \\
\text { - FEC gas warm } \\
\text { water } \\
\text { - FEC oil warm } \\
\text { water } \\
\text { - FEC biomass } \\
\text { warm water } \\
\text { - FEC electricity } \\
\text { warm water } \\
\text { - FEC heat warm } \\
\text { water }\end{array}$ & & & $\begin{array}{l}\text { FEC primary metals production } \\
\text { - FEC primary metals production } \\
\text { - FEC coal primary metals production } \\
\text { - FEC gas primary metals production } \\
\text { - FEC oil primary metals production } \\
\text { - FEC biomass primary metals } \\
\text { production } \\
\text { - FEC electricity primary metals } \\
\text { production } \\
\text { - FEC heat primary metals production }\end{array}$ & & \\
\hline
\end{tabular}


Table A1. Cont.

\begin{tabular}{|c|c|c|c|c|c|c|}
\hline \multirow{3}{*}{$\begin{array}{l}\text { Dimension (of } \\
\text { sustainable } \\
\text { development) }\end{array}$} & \multicolumn{6}{|c|}{ Sector } \\
\hline & \multicolumn{5}{|c|}{ Demand Side } & \multirow{2}{*}{ Electricity \& Heat Supply } \\
\hline & Residential & Passenger Transport & Freight Transport & Manufacturing & Services & \\
\hline & $\begin{array}{l}\text { FEC cooking } \\
\text { - FEC cooking } \\
\text { - FEC coal cooking } \\
\text { - FEC gas cooking } \\
\text { - FEC biomass } \\
\text { cooking } \\
\text { - FEC electricity } \\
\text { cooking }\end{array}$ & & & $\begin{array}{l}\text { FEC non-metallic minerals } \\
\text { production } \\
\text { - FEC non-metallic minerals production } \\
\text { - FEC coal non-metallic minerals } \\
\text { production } \\
\text { - FEC gas non-metallic minerals } \\
\text { production } \\
\text { - FEC oil non-metallic minerals } \\
\text { production } \\
\text { - FEC biomass non-metallic minerals } \\
\text { production } \\
\text { - FEC electricity non-metallic minerals } \\
\text { production } \\
\text { - FEC heat non-metallic minerals } \\
\text { production }\end{array}$ & & \\
\hline & $\begin{array}{l}\text { FEC electrical } \\
\text { appliances }\end{array}$ & & & $\begin{array}{l}\text { FEC paper production } \\
\text { - FEC paper production } \\
\text { - FEC coal paper production } \\
\text { - FEC gas paper production } \\
\text { - FEC oil paper production } \\
\text { - FEC biomass paper production } \\
\text { - FEC electricity paper production } \\
\text { - FEC heat paper production }\end{array}$ & & \\
\hline
\end{tabular}


Table A1. Cont.

\begin{tabular}{|c|c|c|c|c|c|c|}
\hline \multirow{3}{*}{$\begin{array}{l}\text { Dimension (of } \\
\text { sustainable } \\
\text { development) }\end{array}$} & \multicolumn{6}{|c|}{ Sector } \\
\hline & \multicolumn{5}{|c|}{ Demand Side } & \multirow{2}{*}{ Electricity \& Heat Supply } \\
\hline & Residential & Passenger Transport & Freight Transport & Manufacturing & Services & \\
\hline & & & & $\begin{array}{l}\text { FEC wood production } \\
\text { - FEC wood production } \\
\text { - FEC coal wood production } \\
\text { - FEC gas wood production } \\
\text { - FEC oil wood production } \\
\text { - FEC biomass wood production } \\
\text { - FEC electricity wood production } \\
\text { - FEC heat wood production }\end{array}$ & & \\
\hline & $\begin{array}{l}\text { Share of energy } \\
\text { expenditure in } \\
\text { household } \\
\text { expenditure }\end{array}$ & $\begin{array}{l}\text { Share of transport } \\
\text { expenditure in } \\
\text { household expenditure }\end{array}$ & & $\begin{array}{l}\text { Share of costs } \\
\text { - Share of energy costs industry } \\
\text { - Share of energy costs gas } \\
\text { - Share of energy costs heavy oil } \\
\text { - Share of energy costs coal } \\
\text { - Share of energy costs electricity }\end{array}$ & $\begin{array}{l}\text { Share of costs } \\
\text { - Share of energy } \\
\text { costs service } \\
\text { - Share of energy } \\
\text { costs gas } \\
\text { - Share of energy } \\
\text { costs oil } \\
\text { - Share of energy } \\
\text { costs coal } \\
\text { - Share of energy } \\
\text { costs electricity }\end{array}$ & \\
\hline
\end{tabular}


Table A1. Cont.

\begin{tabular}{|c|c|c|c|c|c|c|}
\hline \multirow{3}{*}{$\begin{array}{l}\text { Dimension (of } \\
\text { sustainable } \\
\text { development) }\end{array}$} & \multicolumn{6}{|c|}{ Sector } \\
\hline & \multicolumn{5}{|c|}{ Demand Side } & \multirow{2}{*}{ Electricity \& Heat Supply } \\
\hline & Residential & Passenger Transport & Freight Transport & Manufacturing & Services & \\
\hline & $\begin{array}{l}\text { Public R\&D } \\
\text { expenditures } \\
\text { energy efficiency } \\
\text { buildings }\end{array}$ & \multicolumn{2}{|c|}{$\begin{array}{l}\text { Public R\&D expenditures } \\
\text { - } \text { Public R\&D expenditures for energy efficiency } \\
\text { transport } \\
\text { - Public R\&D expenditures for e-mobility }\end{array}$} & $\begin{array}{l}\text { Public R\&D expenditures energy } \\
\text { efficiency industry }\end{array}$ & & 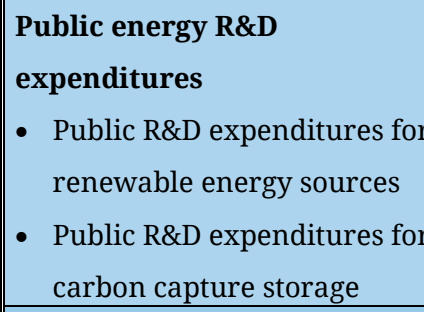 \\
\hline & $\begin{array}{l}\text { Applied patents } \\
\text { energy efficiency } \\
\text { buildings }\end{array}$ & \multicolumn{2}{|c|}{ Applied patents energy efficiency transport } & Applied patents mitigation industry & & $\begin{array}{l}\text { Applied energy technology } \\
\text { patents } \\
\text { - Applied patents mitigation } \\
\text { - Applied patents carbon } \\
\text { capture storage } \\
\end{array}$ \\
\hline \multirow[t]{5}{*}{ Ecological } & $\begin{array}{l}\text { Share of RES } \\
\text { - Share of RES in } \\
\text { HH FEC } \\
\text { - Share of RES } \\
\text { space heating } \\
\text { - Share of RES } \\
\text { warm water } \\
\text { - Share of RES } \\
\text { cooking } \\
\end{array}$ & Share of RES & Share of RES & $\begin{array}{l}\text { Share of RES } \\
\text { - Share of RES industry } \\
\text { - Share of RES chemical sector } \\
\text { - Share of RES primary metals } \\
\text { production } \\
\text { - Share of RES non-metallic minerals } \\
\text { production } \\
\text { - Share of RES paper production } \\
\text { - Share of RES wood production } \\
\end{array}$ & Share of RES & Share of RES in TI \\
\hline & $\mathrm{CO}_{2}$ emissions & $\mathrm{CO}_{2}$ emissions & $\mathrm{CO}_{2}$ emissions & $\mathrm{CO}_{2}$ emissions & $\mathrm{CO}_{2}$ emissions & $\mathrm{CO}_{2}$ emissions \\
\hline & $\mathrm{NO}_{\mathrm{x}}$ emissions & $\mathrm{NO}_{\mathrm{x}}$ emissions & $\mathrm{NO}_{\mathrm{x}}$ emissions & $\mathrm{NO}_{\mathrm{x}}$ emissions & $\mathrm{NO}_{\mathrm{x}}$ emissions & $\mathrm{NO}_{\mathrm{x}}$ emissions \\
\hline & $\mathrm{SO}_{2}$ emissions & $\mathrm{SO}_{2}$ emissions & $\mathrm{SO}_{2}$ emissions & $\mathrm{SO}_{2}$ emissions & $\mathrm{SO}_{2}$ emissions & $\mathrm{SO}_{2}$ emissions \\
\hline & $\begin{array}{l}\mathrm{CO}_{2} \text { efficiency of } \\
\mathrm{FEC}\end{array}$ & $\mathrm{CO}_{2}$ efficiency of FEC & $\mathrm{CO}_{2}$ efficiency of FEC & $\mathrm{CO}_{2}$ efficiency of FEC & $\mathrm{CO}_{2}$ efficiency of FEC & $\mathrm{CO}_{2}$ efficiency of TI \\
\hline
\end{tabular}


Table A1. Cont.

\begin{tabular}{|c|c|c|c|c|c|c|}
\hline \multirow{3}{*}{$\begin{array}{l}\text { Dimension (of } \\
\text { sustainable } \\
\text { development) }\end{array}$} & \multicolumn{6}{|c|}{ Sector } \\
\hline & \multicolumn{5}{|c|}{ Demand Side } & \multirow{2}{*}{ Electricity \& Heat Supply } \\
\hline & Residential & Passenger Transport & Freight Transport & Manufacturing & Services & \\
\hline & $\begin{array}{l}\mathrm{NO}_{\mathrm{x}} \text { efficiency of } \\
\text { FEC }\end{array}$ & $\mathrm{NO}_{\mathrm{x}}$ efficiency of FEC & $\mathrm{NO}_{\mathrm{x}}$ efficiency of FEC & $\mathrm{NO}_{\mathrm{x}}$ efficiency of FEC & $\mathrm{NO}_{\mathrm{x}}$ efficiency of FEC & $\mathrm{NO}_{\mathrm{x}}$ efficiency of TI \\
\hline & $\mathrm{SO}_{2}$ efficiency of FEC & $\mathrm{SO}_{2}$ efficiency of FEC & $\mathrm{SO}_{2}$ efficiency of FEC & $\mathrm{SO}_{2}$ efficiency of FEC & $\mathrm{SO}_{2}$ efficiency of FEC & $\mathrm{SO}_{2}$ efficiency of TI \\
\hline \multirow[t]{6}{*}{ Social } & $\begin{array}{l}\text { Persons who cannot } \\
\text { afford a telephone }\end{array}$ & $\begin{array}{l}\text { New registrations of } \\
\text { passenger cars }\end{array}$ & & & & Low-wage earners \\
\hline & $\begin{array}{l}\text { Persons who cannot } \\
\text { afford a colour TV }\end{array}$ & $\begin{array}{l}\text { New registrations of } \\
\text { electric passenger cars }\end{array}$ & & & & Median hourly earnings \\
\hline & $\begin{array}{l}\text { Persons who cannot } \\
\text { afford a computer }\end{array}$ & $\begin{array}{l}\text { New registrations of } \\
\text { passenger cars } \mathrm{w} \\
\text { alternative drives }\end{array}$ & & & & Temporary contracts \\
\hline & $\begin{array}{l}\text { Persons who cannot } \\
\text { afford a washing } \\
\text { machine }\end{array}$ & $\begin{array}{l}\text { Level of difficulty to } \\
\text { access public transport }\end{array}$ & & & & $\begin{array}{l}\text { Incidence rate of fatal accidents } \\
\text { at work }\end{array}$ \\
\hline & $\begin{array}{l}\text { Persons who cannot } \\
\text { afford internet } \\
\text { connection for } \\
\text { personal use at } \\
\text { home } \\
\end{array}$ & $\begin{array}{l}\text { Persons who cannot } \\
\text { afford a car }\end{array}$ & & & & Flexibility of the work schedule \\
\hline & $\begin{array}{l}\text { Population unable } \\
\text { to keep home } \\
\text { adequately warm by } \\
\text { poverty status }\end{array}$ & & & & & Gender pay gap \\
\hline
\end{tabular}


Table A1. Cont.

\begin{tabular}{|c|c|c|c|c|c|c|}
\hline \multirow{3}{*}{$\begin{array}{l}\text { Dimension (of } \\
\text { sustainable } \\
\text { development) }\end{array}$} & \multicolumn{6}{|c|}{ Sector } \\
\hline & \multicolumn{5}{|c|}{ Demand Side } & \multirow{2}{*}{ Electricity \& Heat Supply } \\
\hline & Residential & Passenger Transport & Freight Transport & Manufacturing & Services & \\
\hline & 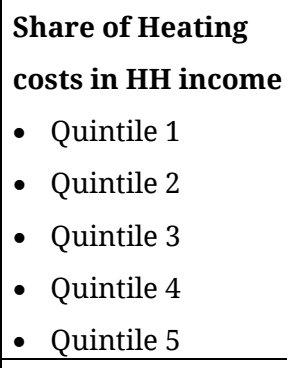 & & & & & \multirow[t]{6}{*}{ Gender employment gap } \\
\hline & $\begin{array}{l}\text { Equipment } \\
\text { rate-fridge }\end{array}$ & & & & & \\
\hline & $\begin{array}{l}\text { Equipment } \\
\text { rate-freezer }\end{array}$ & & & & & \\
\hline & $\begin{array}{l}\text { Equipment } \\
\text { rate-washing } \\
\text { machine } \\
\end{array}$ & & & & & \\
\hline & \begin{tabular}{|l} 
Equipment \\
rate-dishwasher \\
\end{tabular} & & & & & \\
\hline & Equipment rate-TV & & & & & \\
\hline
\end{tabular}

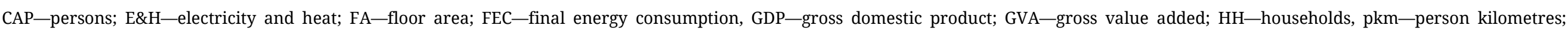
RES—renewable energy sources; R\&D—Research and Development; TI—transformation input; TO—transformation output; tkm—-tonne kilometres.

${ }^{1}$ Energy intensive industry here includes chemical sector, primary metals production, non-metallic minerals production, paper production, and wood production. 
Table A2. Demand-side indicators: Data sources.

\begin{tabular}{|c|c|c|c|}
\hline Dimension & Sector & Indicator & Source \\
\hline \multirow[t]{11}{*}{ Context } & \multirow[t]{2}{*}{ Residential } & Household data & Odyssee database \\
\hline & & HH income (qu.) & EU-SILC \\
\hline & \multirow[t]{7}{*}{ Transport } & Car stock data & Odyssee database \\
\hline & & Modal split & Odyssee database \\
\hline & & Road/rail km & Odyssee database \\
\hline & & Share of e-vehicles & EEA, $\mathrm{CO}_{2}$ emissions from passenger cars \\
\hline & & Share of alternative drives & EEA, $\mathrm{CO}_{2}$ emissions from passenger cars \\
\hline & & Specific $\mathrm{CO}_{2}$ emissions of newly registered cars & EEA, $\mathrm{CO}_{2}$ emissions from passenger cars \\
\hline & & Specific $\mathrm{CO}_{2}$ emissions of car stock & Odyssee database \\
\hline & Industry/Service & GVA & Odyssee database \\
\hline & All sectors & Energy prices & IEA Energy Price Taxes \\
\hline \multirow[t]{9}{*}{ Energy Service } & \multirow[t]{5}{*}{ Residential } & Well-tempered living space proxy: Floor area & Odyssee database \\
\hline & & Illumination Proxy: Floor area & Odyssee database \\
\hline & & Warm water Proxy: Population & Odyssee database \\
\hline & & Cooking Proxy: Households & Odyssee database \\
\hline & & Communication/Entertainment Proxy: Households & Odyssee database \\
\hline & Passenger Transport & Mobility Proxy: pkm & Odyssee database \\
\hline & Freight Transport & Transport of goods proxy: tkm & Odyssee database \\
\hline & Service & Proxy: GVA & Odyssee database \\
\hline & Industry & Proxy: GVA & Odyssee database \\
\hline \multirow[t]{5}{*}{ Economic } & \multirow[t]{3}{*}{ All sectors } & Energy efficiency data & Odyssee database \\
\hline & & R\&D data & IEA, Energy R\&D Expenditures \\
\hline & & Patent data & OECD, EPO database \\
\hline & Residential/Transport & Share of energy expenditure & Eurostat, COICOP \\
\hline & Industry/Service & Share of energy costs & IEA, Odyssee \\
\hline \multirow[t]{2}{*}{ Ecologic } & \multirow[t]{2}{*}{ All sectors } & Share of renewables in sectors & Odyssee database \\
\hline & & Emission data & UNFCCC, National Inventory Reports \\
\hline \multirow[t]{5}{*}{ Social } & Residential/Transport & Affordability data & Eurostat, EU-Silc \\
\hline & \multirow[t]{2}{*}{ Residential } & Equipment rates & Odyssee database \\
\hline & & Share of heating costs (qu.) & Eurostat, Household budget survey \\
\hline & \multirow[t]{2}{*}{ Transport } & New registration of cars & EEA, $\mathrm{CO}_{2}$ emissions from passenger cars \\
\hline & & Accessibility of public transport & Eurostat, EU-Silc \\
\hline
\end{tabular}


Table A3. Supply-side indicators: Data sources.

\begin{tabular}{|c|c|c|}
\hline Dimension & Indicator & Source \\
\hline \multirow[t]{3}{*}{ Context } & Energy Prices & IEA Energy Price Taxes \\
\hline & Carbon prices & EEX \\
\hline & Capacity power plants & IEA Electricity information \\
\hline \multirow[t]{8}{*}{ Economic } & Transformation efficiency electricity plants & IEA Energy Balances \\
\hline & Transformation efficiency CHP & IEA Energy Balances \\
\hline & Transformation efficiency heat plants & IEA Energy Balances \\
\hline & Distribution efficiency electricity & IEA Energy Balances \\
\hline & Distribution efficiency heat & IEA Energy Balances \\
\hline & Transformation input & IEA Energy Balances \\
\hline & Public energy R\&D expenditures & IEA, Energy R\&D Expenditures \\
\hline & Applied energy technology patents & OECD; EPO database \\
\hline \multirow[t]{7}{*}{ Ecological } & $\%$ of RES in Electricity and Heat supply & IEA Energy Balances \\
\hline & $\mathrm{CO}_{2}$ emissions & UNFCCC, National Inventory Reports \\
\hline & $\mathrm{NO}_{\mathrm{x}}$ emissions & UNFCCC, National Inventory Reports \\
\hline & $\mathrm{SO}_{2}$ emissions & UNFCCC, National Inventory Reports \\
\hline & $\mathrm{CO}_{2}$ efficiency of Electricity and Heat supply & UNFCCC, National Inventory Reports \\
\hline & $\mathrm{NO}_{\mathrm{x}}$ efficiency of Electricity and Heat supply & UNFCCC, National Inventory Reports \\
\hline & $\mathrm{SO}_{2}$ efficiency of Electricity and Heat supply & UNFCCC, National Inventory Reports \\
\hline \multirow[t]{8}{*}{ Social } & Low-wage earners & Eurostat, Structure of Earning Survey \\
\hline & Median hourly earnings & Eurostat, Structure of Earning Survey \\
\hline & Collective pay agreement & Eurostat, Structure of Earning Survey \\
\hline & Temporary contracts & Eurostat, Structure of Earning Survey \\
\hline & Incidence rate of fatal accidents at work & Eurostat - European Statistics on accidents at work (ESAW) \\
\hline & Flexibility of the work schedule & Eurostat: Labour Force Survey (LFS) \\
\hline & Gender pay gap & Eurostat: Labour Force Survey (LFS) \\
\hline & Gender employment gap & Eurostat - Structure of Earnings Survey (SES) \\
\hline
\end{tabular}




\section{REFERENCES}

1. UNFCCC. National Inventory Reports. New York (NY, US): UNFCCC; 2019.

2. TWI2050-The World in 2050. Transformations to Achieve the Sustainable Development Goals. Laxenburg (Austria): TWI2050; 2018. Available from: http://twi2050.org. Accessed $2020 \mathrm{Feb} 7$.

3. Bierman F, Kanie N, Kim RE. Global governance by goal-setting: the novel approach of the UN Sustainable Development Goals. Curr Opin Environ Sustain. 2017;26-27:26-31. https://doi.org/10.1016/j.cosust.2017.01.010

4. Mulholland E, Dimitrova A, Hametner M. SDG Indicators and Monitoring: Systems and Processes at the Global, European, and National Level. Vienna (Austria): ESDN Office; 2018. Report No.: Quarterly Report 48.

5. Nilsson M, Griggs D, Visbeck M. Policy: Map the interactions between Sustainable Development Goals. Nature. 2016;534:320-2. doi: $10.1038 / 534320$ a

6. McCollum DL, Echeverri LG, Busch S, Pachauri S, Parkinson S, Rogelj J, et al. Connecting the sustainable development goals by their energy inter-linkages. Environ Res Lett. 2018;13:033006. doi: 10.1088/1748-9326/aaafe3

7. Blanc DL. Towards Integration at Last? The Sustainable Development Goals as a Network of Targets. Sustain Dev. 2015;23:176-87. doi: 10.1002/sd.1582

8. Nilsson M, Griggs D, Visbeck M, Ringler A. A draft framework for understanding SDG interactions. Paris (France): International Council for Science; 2016.

9. Spangenberg JH. Hot Air or Comprehensive Progress? A Critical Assessment of the SDGs. Sustain Dev. 2017;25:311-21. doi: 10.1002/sd.1657

10. Türkeli S. Complexity and the Sustainable Development Goals: A Computational Intelligence Approach to Support Policy Mix Designs. J Sustain Res. 2020;2:e200006. https://doi.org/10.20900/jsr20200006

11. Cullen JM, Allwood JM. The efficient use of energy: Tracing the global flow of energy from fuel to service. Energy Policy. 2010;38:75-81.

12. Gouveia JP. Projections of energy services demand for residential buildings: Insights from a bottom-up methodology. Energy. 2012;47:430-42. doi: 10.1016/j.energy.2012.09.042

13. Haas R, Nakicenovic N, Ajanovic A, Faber T, Kranzl L, Müller A, et al. Towards sustainability of energy systems: A primer on how to apply the concept of energy services to identify necessary trends and policies. Energy Policy. 2008;36:4012-21.

14. Köppl A, Kettner C, Kletzan-Slamanig D, Schleicher S, Damm A, Steininger K, et al. Energy Transition in Austria: Designing Mitigation Wedges. Energy Environ. 2014;25:281-304. doi: 10.1260/0958-305X.25.2.281

15. Ma L, Allwood JM, Cullen JM, Li Z. The use of energy in China: Tracing the flow of energy from primary source to demand drivers. Energy. 2012;40: 174-88. doi: 10.1016/j.energy.2012.02.013

16. Sovacool BK. Conceptualizing urban household energy use: Climbing the “Energy Services Ladder.” Energy Policy. 2011;39:1659-68. doi: 10.1016/j.enpol.2010.12.041 
17. Sovacool BK. Security of energy services and uses within urban households. Current Opinion in Environmental Sustainability. 2011;3:218-24. doi: 10.1016/j.cosust.2011.06.004

18. Breuer A, Janetschek H, Malerba D. Translating Sustainable Development Goal (SDG) Interdependencies into Policy Advice. Sustainability. 2019;11:2092. doi: 10.3390/su11072092

19. TWI. The world in 2050-Annual Report 2017. Laxenburg (Austria): IIASA; 2017.

20. European Commission. Communication from the Commission to the Council and the European Parliament on the review of the Sustainable Development Strategy-A platform for action. Brussels (Belgium): European Commission; 2005. Report No.: /* COM/2005/0658 final */.

21. UN Social and Economic Council. Report of the Inter-Agency and Expert Group on Sustainable Development Goal Indicators. New York (NY, US): UN; 2016. Report No.: E/CN.3/2016/2/Rev.1.

22. UN. Critical milestones towards coherent, efficient and inclusive follow up and review at the global level Report of the Secretary-General. New York (NY, US): UN; 2016. Report No.: A /70/684.

23. UNCSD. Indicators of Sustainable Development: Guidelines and Methodologies. Rio de Janeiro (Brazil): UNCSD; 2001.

24. General Assembly of the UN. Transforming our World: The 2030 Agenda for Sustainable Development. New York (NY, US): General Assembly of the UN; 2015. Report No.: Seventieth session Agenda items 15 and 116. Available from: https://sustainabledevelopment.un.org/post2015/transformingourworld. Accessed 2020 Feb 7.

25. Bertelsmann Stiftung and Sustainable Development Solutions Network (SDSN). SDG Index \& Dashboards A Global Report. Gütersloh (Germany): SDSN; 2016.

26. Statistics Austria. STATISTICS BRIEF AGENDA 2030-SDG-INDIKATOREN. Vienna (Austria): Statistics Austria; 2018.

27. Schepelmann P, Goossens Y, Makipaa A. Towards Sustainable Development Alternatives to GDP for measuring progress. Wuppertal (Germany): Wuppertal Institute; 2008.

28. IEA, IAEA. Indicators for Sustainable Energy Development. Paris (France): IAEA; 2001.

29. IAEA, IEA. Energy Indicators for Sustainable Development: Guidelines and Methodologies. Paris (France): IAEA; 2005.

30. Streimikiene D. Indicators for sustainable energy development in Lithuania. Nat Resour Forum. 2005;29:322-33. doi: 10.1111/j.1477-8947.2005.00144.x

31. Pérez D, López I, Berdellans I. Evaluation of energy policy in Cuba using ISED. Nat Resour Forum. 2005;29:298-307. doi: 10.1111/j.1477-8947.2005.00142.x

32. Medina-Ross JA, Mata-Sandoval JC, López-Pérez R. Indicators for sustainable energy development in Mexico. Nat Resour Forum. 2005;29:308-21. doi: 10.1111/j.1477-8947.2005.00143.x 
33. Davidsdottir B, Basoli DA, Fredericks S, Enterline CL. Measuring sustainable energy development with a three-dimensional index. In: Frontiers in Ecological Economic Theory and Application. Cheltenham (UK): Edward Elgar Publishing; 2007. p. 303-30.

34. Ibarrarán Viniegra ME, Davidsdottir B, Gracida Zurita R. Índice de sustentabilidad energética: estimaciones para México. Principios estudios de economía política. 2009;85-100. Spanish.

35. Martchamadol J, Kumar S. Thailand's energy security indicators. Renew Sustain Energy Rev. 2012;16:6103-22.

36. Martchamadol J, Kumar S. An aggregated energy security performance indicator. Appl Energy. 2013;103:653-70. doi: 10.1016/j.apenergy.2012.10.027

37. Martchamadol J, Kumar S. The Aggregated Energy Security Performance Indicator (AESPI) at national and provincial level. Appl Energy. 2014;127:219-38. doi: 10.1016/j.apenergy.2014.04.045

38. Portugal-Pereira J, Esteban M. Implications of paradigm shift in Japan's electricity security of supply: A multi-dimensional indicator assessment. Appl Energy. 2014;123:424-34. doi: 10.1016/j.apenergy.2014.01.024

39. Sovacool BK, Mukherjee I. Conceptualizing and measuring energy security: A synthesized approach. Energy. 2011;36:5343-55. doi: 10.1016/j.energy.2011.06.043

40. National Climate Assessment and Development Advisory Committee. National Climate Indicators System Report. Montana (US): Numerical Terradynamic Simulation Group Publications; 2014. p. 1-157. Available from: https://scholarworks.umt.edu/ntsg_pubs/376. Accessed 2020 Feb 7.

41. Germanwatch. The Climate Change Performance Index 2015. Available from: https://germanwatch.org/en/9472. Accessed 2018 Oct 23.

42. Bernauer T, Böhmelt T. National climate policies in international comparison: The Climate Change Cooperation Index. Environ Sci Policy. 2013;25:196-206. doi: 10.1016/j.envsci.2012.09.007

43. Odyssee. Odyssee database. 2019. Available from: https://www.indicators.odyssee-mure.eu/energy-efficiency-database.html. Accessed 2020 Feb 7.

44. European Energy Agency. CO2 emissions from passenger cars. Copenhagen (Denmark): European Energy Agency; 2019.

45. IEA. Energy Balances. Paris (France): IEA; 2019.

46. IEA. Energy Price Taxes. Paris (France): IEA; 2019.

47. IEA. Energy R\&D Expenditures. Paris (France): IEA; 2019.

48. Eurostat. Household budget survey. Brussels (Belgium): Eurostat; 2019.

49. Eurostat. European Statistics on accidents at work (ESAW). Brussels (Belgium): Eurostat; 2019.

50. Eurostat. Labour Force Survey. Brussels (Belgium): Eurostat; 2019.

51. Eurostat. Structure of Earning Survey. Brussels (Belgium): Eurostat; 2019.

52. EU. EU Silc-Community Statistics on Income and Living Conditions. Brussels (Belgium): EU; 2019;

53. OECD. EPO database. 2019. Available from: https://stats.oecd.org/. Accessed 2020 Feb 7. 
54. EEX. European Spot market primary auction prices EUAs. Leipzig (Germany): EEX; 2019.

55. Littig B. Lebensführung revisited. Zur Aktualisierung eines Konzepts im Kontext der sozial-ökologischen Transformationsforschung. Berlin (Germany): Rosa-Luxemburg-Stiftung; 2016. German.

56. Pimminger I, Wroblewski A. Von geschlechtsdifferenzierten Daten zu Gender- und Gleichstellungsindikatoren. In: Wroblewski A, Kelle U, Reith F, editors. Gleichstellung messbar machen: Grundlagen und Anwendungen von Gender- und Gleichstellungsindikatoren. Wiesbaden (Germany): Springer Fachmedien; 2017. p. 61-79. German. doi: 10.1007/978-3-658-13237-8_4

57. Pimminger I. Theoretische Grundlagen zur Operationalisierung von Gleichstellung. In: Wroblewski A, Kelle U, Reith F, editors. Gleichstellung messbar machen: Grundlagen und Anwendungen von Gender- und Gleichstellungsindikatoren. Wiesbaden (Germany): Springer Fachmedien; 2017. p. 39-60. German. doi: 10.1007/978-3-658-13237-8_3

58. Röhr U. Genderaspekte des Klimawandels-Ursachen, Auswirkungen, Gestaltungsmacht. Klimawandel, Klimaschutz und Gender. Bonn (Germany): Friedrich-Engelbert-Stiftung; 2008.

59. Räty R, Carlsson-Kanyama A. Energy consumption by gender in some European countries. Energy Policy. 2010;38:646-9. Available from: https://ideas.repec.org/a/eee/enepol/v38y2010i1p646-649.html. Accessed 2020 Feb 7.

60. Kettner C, Kletzan-Slamanig D, Köppl A, Littig B, Zielinska I. A Cross-Country Comparison of Sustainable Energy Development in Selected EU Members. J Sustain Res. 2019;1:e190017. https://doi.org/10.20900/jsr20190017

61. Guijarro F, Poyatos JA. Designing a Sustainable Development Goal Index through a Goal Programming Model: The Case of EU-28 Countries. Sustainability. 2018;10:3167. doi: 10.3390/su10093167

62. Guijarro F. A Multicriteria Model for the Assessment of Countries' Environmental Performance. Int J Environ Res Public Health. 2019;16:2868. doi: 10.3390/ijerph16162868

63. Biggeri M, Clark DA, Ferrannini A, Mauro V. Tracking the SDGs in an 'integrated' manner: A proposal for a new index to capture synergies and trade-offs between and within goals. World Dev. 2019;122:628-47. doi: 10.1016/j.worlddev.2019.05.022

How to cite this article:

Kettner C, Kletzan-Slamanig D, Köppl A; Littig B, Zielinska I. Monitoring Sustainable Development: Climate and Energy Policy Indicators. J Sustain Res. 2020;2(3):e200027. https://doi.org/10.20900/jsr20200027 